\title{
NABAVNA POLITIKA I IZGRADNJA \\ KNJIŽNIČNIH ZBIRKI U VISOKOŠKOLSKIM \\ KNJIŽNICAMA SVEUČILIŠTA JOSIPA JURJA \\ STROSSMAYERA U OSIJEKU
}

\author{
ACQUISITION POLICY AND FORMATION \\ OF LIBRARY COLLECTIONS IN HIGHER EDUCATION \\ INSTITUTIONS OF JOSIP JURAJ STROSSMAYER \\ UNIVERSITY OF OSIJEK
}

\author{
Gordana Gašo \\ Filozofski fakultet \\ Sveučilište u Osijeku \\ ggaso@ffos.hr \\ Jasminka Mihaljević \\ Ekonomski fakultet \\ Sveučilište u Osijeku \\ jasminka.mihaljevic@efos.hr \\ Ljiljana Siber \\ Pravni fakultet \\ Sveučilište u Osijeku \\ ljsiber@pravos.hr
}

UDK / UDC 025.2: 658.71(497.5 Osijek) Prethodno priopćenje / Preliminary paper Primljeno / Received: 15. 11. 2019. Prihvaćeno / Accepted: 5. 11. 2020.

\section{Sažetak}

Cilj. Rad prikazuje stanje i promjene u nabavnoj politici kao važnoj fazi u procesu izgradnje zbirki u visokoškolskim knjižnicama Sveučilišta Josipa Jurja Strossmayera

Vjesnik bibliotekara Hrvatske 63, 1-2(2020), 131-159 ISSN 0507-1925 
u Osijeku temeljom longitudinalnog istraživanja provedenog tijekom ožujka 2015. i ožujka 2019. godine.

Istraživanje ima za cilj utvrditi na koji se način provodi nabava prema vrsti građe i obliku nabave, ima li značajnijih promjena u izgradnji knjižničnih zbirki u promatranom razdoblju te postoje li pisani dokumenti fakulteta i knjižnice kojima je uređena izgradnja knjižničnih zbirki, na koji se način provodi kontinuirana i sustavna nabavna politika i koliko matična ustanova unutar koje djeluju knjižnice na Sveučilištu u Osijeku utječe na donošenje odluka u upravljanju zbirkama i koji je najbolji način njihova rješavanja.

Metodologija. Istraživanje je provedeno uz pomoć kvantitativnih i kvalitativnih metoda. Kvantitativni podatci dobiveni su online anketnim upitnikom koji je sudionicima istraživanja bio dostupan putem poveznice proslijeđene elektroničkom poštom. Sudionici istraživanja voditelji su visokoškolskih knjižnica pri fakultetima, akademijama i odjelima, sastavnicama Sveučilišta u Osijeku. U istraživanju 2015. godine sudjelovalo je 13, a u istraživanju 2019. godine 15 ispitanika. Kvalitativni podatci dobiveni su polustrukturiranim intervjuom provedenim tijekom listopada 2020. godine. U intervjuu je sudjelovalo 5 voditelja visokoškolskih knjižnica i 1 djelatnik Službe nabave Gradske i sveučilišne knjižnice Osijek.

Rezultati. Rezultati upitnika upotrijebljeni su za raspravu na zajedničkom sastanku voditelja visokoškolskih knjižnica Sveučilišta u Osijeku o koristima istraživanja u pogledu mogućnosti za postavljanje matrice ili okvira za pisanu politiku nabave kao faze u procesu izgradnje zbirki u visokoškolskim knjižnicama. Na temelju analize provedenog istraživanja konkretizirani su zaključci koji upućuju na mogućnosti izgradnje kvalitetnijih knjižničnih zbirki na lokalnoj i na nacionalnoj razini kroz zajedničku suradnju.

Originalnost/vrijednost. Doprinos je rada u mogućnosti postavljanja kriterija koji mogu poslužiti kao temelj za organizaciju i nabavu knjižničnih zbirki u svim visokoškolskim knjižnicama, uz uvažavanje različitosti među pojedinim fakultetima, kao i mogućih rješenja politike koordinirane nabave matičnog Sveučilišta.

Ključne riječi: izgradnja knjižničnih zbirki, nabavna politika, smjernice za izgradnju knjižničnih zbirki, upravljanje knjižničnim zbirkama, visokoškolske knjižnice

\section{Abstract}

Goal / Purpose. The paper aims to present the state and changes in the acquisition policy and building of library collections in the higher education institutions libraries of Josip Juraj Strossmayer University of Osijek based on a longitudinal research conducted in March 2015 and in March 2019.

The research aims to determine the way the acquisitions are carried out according to the type of library material and the form of acquisition, point to the changes that have taken place in organizing library collections in the observed period and explore whether 
there are written guidelines of the faculties and libraries regulating the acquisition and building of library collections, as well as the level of influence of the particular university unit in which the libraries of the University of Osijek are active, when it comes to decision-making in managing the collections and the best solution practices.

Methodology. The research was conducted by applying qualitative and quantitative methods. The quantitative data were collected by an online questionnaire available to the research participants via a link forwarded by e-mail. The participants in the research were the head librarians of the higher education libraries at the faculties, academies, and departments, constituencies of the University of Osijek. In the 2015 research there were 13, and in the 2019 research there were 15 participants. The qualitative data were collected by a semi-structured interview conducted in October 2020. Five head librarians from the higher education institution libraries and one employee in the Acquisition Services of the City and University Library of Osijek participated in the interview.

Results. The results of the questionnaire were used for a discussion at a joint meeting of the head librarians of the higher education libraries of the University of Osijek, on the benefits of the research in terms of setting a matrix or a framework for a written acquisition policy and building of collections in higher education institutions libraries. The analysis results of the conducted research led to the conclusions that indicated a possibility of improving the quality of library collections through cooperation at both local and national levels.

Originality / contribution. The paper contributes to the possibility of setting the criteria that can serve as the foundation for the organization and setting acquisition guidelines for library collections in all higher education institutions libraries, taking into account the differences between particular university constituencies and possible solutions to coordinate the acquisition policy of the University.

Keywords: acquisition policy, building of library collections, guidelines for building of library collections, higher education institutions libraries, library collection management

\section{Uvod}

Digitalno doba donijelo je drugačije medije i utjecalo na društvene promjene, nove načine komuniciranja, ali i potrebu za novim načinom izgradnje, nabave knjižničnih zbirki radi zadovoljavanja potreba korisnika, prvenstveno u pogledu pružanja relevantnih informacijskih izvora.

Nabava građe, izgradnja i upravljanje knjižničnim zbirkama u visokoškolskim knjižnicama temelj je knjižničnog poslovanja i polazište je za ostale djelatnosti 
unutar knjižničnog poslovanja vodeći se propisanim standardima za visokoškolske knjižnice u Republici Hrvatskoj ${ }^{1}$, pisanih smjernica za nabavu i relevantnim primjerima dobre prakse drugih knjižnica.

U hrvatskoj stručnoj i znanstvenoj literaturi nema puno radova o nabavi i nabavnoj politici visokoškolskih knjižnica. U pedesetogodišnjem razdoblju najviše je radova objavljeno u Vjesniku bibliotekara Hrvatske i zbornicima Dana specijalnih i visokoškolskih knjižnica u Republici Hrvatskoj. Prvi rad o nabavi i nabavnoj politici B. Hergešić ${ }^{2}$ objavljen je davne 1959. Drugi se radovi odnose na nabavu građe u sklopu određenog fakulteta (T. Krajna i H. Markulin ${ }^{3}$; M. Šušak Lukačević, S. Hasenay i I. Šuvak-Pirić4), o konzorcijskoj nabavi časopisa, e-knjiga i baza podataka (I. Mihel i V. Gržetićs; A. Martek6) ili nabave i izgradnje zbirki u integriranom sveučilištu (T. Grujić ${ }^{7}$ ), kao i u sveučilišnom knjižničnom sustavu (Z. Majstorović i K. Ivić8; Z. Majstorović i J. Leščić ${ }^{9}$; G. Peleš ${ }^{10}$ ), utjecaju promjena, preoblikovanju i pristupu istraživanja zbirki (T. Aparac Jelušicićn ${ }^{11}$ T. Aparac Jelušić i T. Dragij ${ }^{12}$ ),

1 Važeći su standardi iz 1990.: Standardi za visokoškolske knjižnice u Republici Hrvatskoj. // Vjesnik bibliotekara Hrvatske 33, 1-4(1990), 201-210. U završnoj je fazi izrada i usvajanje novih standarda za visokoškolske, sveučilišne i znanstvene knjižnice.

2 Hergešić, B. O nabavi i nabavnoj politici. // Vjesnik bibliotekara Hrvatske 5, 1-4(1958-1959), 9-23.

3 Krajna, T.; H. Markulin. Nabava knjižnične građe u visokoškolskim knjižnicama. // Vjesnik bibliotekara Hrvatske 54, 3(2011), 21-42. Dostupno i na: https://www.hkdrustvo.hr/vjesnik-bibliotekara-hrvatske/index.php/vbh/article/view/358. [citirano: 2020-07-30].

4 Šušak Lukačević, M.; S. Hasenay; I. Šuvak-Pirić. Izgradnja zbirke periodike razmjenom časopisa Mathematical comunications u knjižnici Odjela za matematiku Sveučilišta u Osijeku. // Knjižničarstvo 17, 2(2103), 57-74. [citirano: 2020-07-30]. Dostupno na: https://hrcak.srce.hr/239689.

5 Mihel, I.; V. Gržetić. Nabava časopisa u 2002. godini: konzorcijski pristup: korak ka ažurnijem i obuhvatnijem informiranju. // Kemija u industriji 51, 6(2002), 285-289.

6 Martek, A. Konzorcijska nabava u Hrvatskoj: stanje i perspektiva. // Vjesnik bibliotekara Hrvatske 54, 3(2011), 79-94. Dostupno i na:https://www.hkdrustvo.hr/vjesnik-bibliotekara-hrvatske/index.php/vbh/article/view/361. [citirano: 2020-07-30].

7 Grujić, T. Nabava literature za potrebe Sveučilišta u Puli: možemo i bolje! // 13. dani specijalnih i visokoškolskih knjižnica: zbornik radova, Opatija 2013. / ur. Ivana Hebrang Grgić i Vesna Špac. Zagreb: Hrvatsko knjižničarsko društvo, 2014. Str. 309-318.

8 Majstorović, Z.; K. Ivić. Izgradnja zbirki u sveučilišnom knjižničnom sustavu: model. // Vjesnik bibliotekara Hrvatske 54, 3(2011), 43-67. Dostupno i na: https://www.hkdrustvo.hr/vjesnik-bibliotekara-hrvatske/index.php/vbh/article/view/359. [citirano: 2020-07-30].

9 Leščić, J.; Z. Majstorović. Conspectus model IFLA-e: prikaz načela i njihove primjene u praksi. // 11. dani specijalnih i visokoškolskih knjižnica, Opatija, 2009.: zbornik / ur. Tamara Krajna i Alisa Martek. Zagreb: Hrvatsko knjižničarsko društvo, 2010., str. 288-297.

10 Peleš, G. Nabavna politika kao pokazatelj odnosa između sveučilišnih (fakultetskih) biblioteka i Nacionalne i sveučilišne biblioteke. // Vjesnik bibliotekara Hrvatske 33, 1-4(1990), 53-56.

11 Aparac-Jelušić, T. Utjecaj promjena u akademskom obrazovanju na preoblikovanje knjižničnih službi i usluga. // Glasnik društva bibliotekara Split 7(2000), 39-51.

12 Aparac-Jelušić, T.; M. Dragija. Pristup i metodologija istraživanja kvalitete zbirki u knjižnicama visokih učilišta. // Glasnik društva bibliotekara Split 7(2000), 162-168. 
nabava knjiga otkupom (Lj. Siber i S. Lukačević ${ }^{13}$ ), razvojem zbirki i stavovima korisnika (V. Radovan i J. Kovačević14).

U stranoj literaturi za teorijski okvir za upravljanje zbirkama i nabavnu politiku u knjižnicama nezaobilazni su autori G. E. Evans i M. Saponaro Zarnowski ${ }^{15}$; P. Clayton i G. E. Gorman ${ }^{16}$, zatim niz radova na temu istraživanja iz časopisa $\mathrm{Li}$ brary Collections, Acquisitions \& Technical Services već spomenutog autora M. Gormana $^{17}$ te autora T. Horavea ${ }^{18}$; D. Bullisa, i R.Smith ${ }^{19}$; T. Leonhardta ${ }^{20}$; J. S. Lewis ${ }^{21}$ i drugih.

\section{Upravljanje knjižničnim zbirkama u visokoškolskim knjižnicama - teorijski okvir}

Središte zanimanja knjižničarske prakse izgradnja je zbirki kako bi bile dostupne korisnicima. Pojmovi upravljanje zbirkama (eng. collection management) i izgradnja zbirki (eng. collection development) različito se rabe u knjižničarskoj zajednici, ali u novije vrijeme prevladava sintagma upravljanje zbirkama koja obuhvaća raznolike etape tog složenog procesa. P. Clayton i G. Gorman ${ }^{22}$ navode Jenkinsa i Morleya koji upravljanje zbirkama definiraju kao sustavno upravljanje planiranjem, izgradnjom, financiranjem, vrednovanjem i uporabom knjižničnih

13 Siber, Lj.; S. Lukačević. Otkup knjiga Ministarstva kulture i Ministarstva znanosti, obrazovanja i sporta: utjecaj na izgradnju knjižnog fonda Gradske i sveučilišne knjižnice Osijek u razdoblju od 1998. do 2013. // Vjesnik bibliotekara Hrvatske 60, 2-3(2017), 80-100. Dostupno i na: https://www. hkdrustvo.hr/vjesnik-bibliotekara-hrvatske/index.php/vbh/article/view/578. [citirano: 2020-07-30].

14 Vrana, R.; J. Kovačević. Razvoj knjižničnih zbirki kao preduvjet i mjera razvoja knjižnice. // Vjesnik bibliotekara Hrvatske 60, 1(2017), 79-12. Dostupno i na: https://www.hkdrustvo.hr/ vjesnik-bibliotekara-hrvatske/index.php/vbh/article/view/538. [citirano: 2020-08-30].

15 Evans, G. E.; M. Saponaro Zarnowski. Developing library and information center collections. 5th ed. Wesport; London: Libraries Unlimited, 2005.

16 Clayton, P.; G. E. Gorman. Managing information resources in libraries: collection management in theory and practice. London: Library Association Publishing, 2001.

17 Gorman, M. Collection development in interesting times: a summary. // Library Collections, Acquisitions and Technical Services 27, 4(2003), 459-462. DOI: https://doi.org/10.1080/146490 55.2003.10765950.

18 Horava, T. Challenges and possibilities for collection management in a digital age. // Library Resources \& Techical Services 54, 3(2010), 144-145. DOI: https://doi.org/10.5860/lrts.54n3.142. 19 Bullis, D. R.; L. Smith. Looking back, moving forward in the digital age: a review of the collection management and development literature, 2004-8. // University Libraries Faculty Scholarship 26(2011), 205-220. [citirano: 2020-07-30]. Dostupno na: https://scholarsarchive.library. albany.edu/ulib_fac_scholar/26/.

20 Leonhardt, T. The gifts and exchange function in ARL libraries: now and tomorrow. // Library Acquisitions: Practice \& Theory 21, 2(1997), 141-149. Citirano prema: Siber, Lj.; S. Lukačević, nav. dj., str. 82.

${ }^{21}$ Lewis, J. S. An assessment of publisher quality by political science librarians. // College \& Research Libraries 61, 4(2000), 313-323. Citirano prema: Siber, Lj.; S. Lukačević. Nav. dj., str. 86.

${ }^{22}$ Usp. Clayton, P.; G. E. Gorman. Nav. dj., str. 17. 
zbirki tijekom dužeg vremenskog razdoblja u svrhu ostvarivanja određenih ciljeva ustanove. Prema tom izgradnja zbirki jedan je od elemenata upravljanja zbirkama.

G. E. Evans upravljanje zbirkama definira kao aktivnost koja se odnosi na knjižnično okruženje (u tradicionalnom smislu) i koja stavlja naglasak na prikupljanje materijala koji potječe od drugih ustanova, što je različito od upravljanja informacijskim izvorima koje pokriva kako izvore koji potječu iz drugih ustanova, tako i one koje posjeduje sama knjižnica. ${ }^{23}$

Autori D. R. Bullis i L. Smith ${ }^{24}$ naglašavaju kako je kontinuirano vrednovanje i redefiniranje odgovornosti za upravljanje zbirkama postalo važna tema. S obzirom na promjene koje je donijelo digitalno doba, visokoškolski knjižničari prilagođavali su politiku, knjižničnu organizacijsku strukturu i praksu upravljanja kako bi zbirke i usluge ostale relevantne. T. Horava ${ }^{25}$ od temeljnih vrijednosti koje bi trebale biti prisutne pri upravljanju zbirkama navodi jednakost pristupa, intelektualnu slobodu, otvoreni pristup, upravljanje i vjerodostojnost. Autor daje deset preporuka $^{26}$ za redefiniranje upravljanja zbirkama u digitalnom okruženju: fokusirati se na održive izvore, istraživati zadovoljstva korisnika postojećim zbirkama, ali i alatima koje knjižnica posjeduje za podršku (poput programa za upravljanje referencama, mogućnosti dostave dokumenata, Open URL-a za povezivanje, društvenih medija) te tehnologijom (mobilni uređaji i čitači), dopunjavati zbirke u skladu s promjenama studijskih programa, donijeti strategiju o izboru najboljeg formata među više različitih formata. Promjene i preispitivanje dugogodišnje prakse mogu dovesti do promjene izvora i novih i kreativnih načina za njihovu dostavu korisnicima. Nadalje važno je uspostaviti ravnotežu između natjecanja i suradnje među visokoškolskim knjižnicama, pri čemu su posebno važni međuknjižnična posudba i koordinirana nabava te razvijati partnerstvo s izdavačima i dobavljačima. ${ }^{27}$ Jedna je od važnih preporuka vrednovanje postojećih zbirki, kako tiskanih, tako i digitalnih, koje su dostupne korisnicima putem knjižnice, uključivanjem korisnika u proces vrednovanja i uporabom novih tehnika i metoda. Da bi knjižničari uspješno slijedili navedene preporuke, trebaju usavršavati svoje vještine, stručnost i obrazovanje u skladu s razvojem informacijskih tehnologija i promjenama u okruženju. Navedeni autor zaključuje „da bez velikih, bogatih zbirki, bez stručnjaka, koji će

23 Evans, G. E. Developing library and information center collections, 4th. Libraries Unlimited, 2000. Str. 19-20. Citirano prema: Clayton, P.; G. E. Gorman. Nav. dj., str. 17-18.

${ }^{24}$ Usp. Bullis, D. R.; L. Smith. Nav. dj., str. 214.

25 Usp. Horava, T. Nav. dj., str. 144.

26 Usp. isto, str. 149-151.

27 Profesionalan odnos i kontinuirana suradnja doprinosi uštedi financijskih sredstava kroz povoljne rabate prilikom kupnje te omogućavanje besplatnog probnog pristupa elektroničkim izvorima na određeno probno razdoblje 
usmjeravati i upućivati korisnike, nove tehnologije imaju vrlo ograničeno djelovanje“. 28

G. E. Evans i M. Z. Saponaro navode kako knjižnica više nije u središtu kao „riznica za skladištenje informacija“, već su središte u današnjem vremenu krajnji korisnici i njihove informacijske potrebe ${ }^{29}$, a da bi se odgovorilo na potrebe korisnika, knjižnica treba sustavno i planski izgrađivati svoje zbirke i vrednovati knjižnični fond.

Sve te promjene u posljednjim desetljećima u visokom školstvu, tehnologiji i unutarnjoj organizaciji sveučilišnih sustava izazov su za visokoškolske knjižnice. One moraju imati jasne ciljeve određene strategijskim planom razvoja, kao i operativne planove koji ih usmjeravaju prema okolini i prepoznavanju promjena ${ }^{30}$ kako bi ispunili svoju svrhu i zadaću.

T. Aparac-Jelušić i M. Dragija ${ }^{31}$ definirale su zadaće visokoškolskih knjižnica $i$ istaknule da te knjižnice trebaju ,graditi zbirke, organizirati djelotvoran sustav obavještavanja i osigurati svojim korisnicima dostupnost literature i informacija." Isto tako navode njihove tri osnovne zadaće: obrazovnu, informacijsku i komunikacijsku. ${ }^{32}$ Obrazovna, kulturna, stručna i informacijska razina korisničkih potreba te podizanje kvalitete društvenog standarda i ostvarivanje demokratskih prava omogućavanjem slobodnog pristupa informacijama vodilja su u stvaranju i pristupu zbirkama knjižnica. ${ }^{33}$ Prema nekim istraživanjima, G. E. Evans i M.Z. Saponaro ${ }^{34}$ zaključili su da u formalnom sustavu informacijske potrebe određuje razina obrazovanja korisnika, zatim dohodak, kulturna pozadina i drugi ekonomski pokazatelji. U visokoškolskim knjižnicama vrlo važnu ulogu i utjecaj na sadržaj zbirki imaju, kao neformalni izvori, mišljenja kolega i nastavnika s kojima knjižničari usko surađuju.

Naravno da se sve navedene aktivnosti korigiraju i usklađuju s aktualnim financijskim mogućnostima knjižnice i nakladničkom ponudom. ${ }^{35}$

Relevantnost i konzistentnost knjižničnih zbirki važnija je od njezine veličine. Izgradnji dobre zbirke prethode pomno razrađeni postupci - od istraživanja zajednice korisnika i njezinih potreba preko kvalitetnog stvaranja nabavne politike i selekcije ili odabira knjižnične građe do postupaka nabave, evaluacije i

\footnotetext{
28 Usp. Aparac-Jelušić, T. Nav. dj., str. 49.

29 Usp. Evans, G. E.; M. Saponaro Zarnowski. Nav. dj., str. 1-10.

30 Majstorović, Z. ; K. Ivić. Nav. dj., str. 44.

31 Usp. Aparac-Jelušić, T.; M. Dragija. Nav. dj., str. 163.

32 Usp. isto, str. 154.

33 Usp. Siber Lj. ; S. Lukačević. Nav. dj., str. 85.

34 Usp. Evans, E.G.; M. Saponaro Zarnowski. Nav. dj. 21.

35 Usp. Siber, Lj.; S. Lukačević. Nav. dj., str. 85.
} 
pročišćavanja zbirki. Također, P. Clayton i G. Gorman ${ }^{36}$ ističu važnost sustavnog dokumentiranja procesa izgradnje knjižničnih zbirki u praksi. Autori tvrde kako je za učinkovito upravljanje zbirkama neophodan usvojeni plan izgradnje zbirke jer je on podskup cjeline upravljanja zbirkama. Plan izgradnje zbirki samo je dio plana upravljanja zbirkama knjižnice, a skup je stavova o općim načelima izgradnje zbirke koja oslikava njihovu svrhu i sadržaj koji je namijenjen podjednako zaposlenima i javnosti (korisnicima).

Porast dokumenata na elektroničkom tržištu informacija, promjena znanstvene komunikacije i usvajanje znanja, razvoj u sustavima za knjižnično upravljanje, modeli pretplate i licenciranja te slobodan pristup informacijama na internetu utječu na koncept tradicionalnih ideja vezanih uz knjižnične zbirke koje ima za posljedicu razvoj novih modela izgradnje i upravljanja zbirkama. S. Corrall ${ }^{37}$ drži da je alternativa tradicionalnim pojmovima za aktivnosti povezane sa zbirkama u digitalnom okruženju upravljanje informacijskim resursima te upravljanje sadržajem. M. Gorman ${ }^{38}$ predlaže definiciju zbirke na temelju pristupa koji obuhvaćaju četiri razine, uključujući lokalne fizičke dokumente u vlasništvu knjižnica; građu u vlasništvu drugih knjižnica dostupnu kroz skupne kataloge i uslugom međuknjižnične posudbe i nematerijalnih izvora koji nisu u vlasništvu knjižnice, ali su dostupni preko nje, kao što su besplatni elektronički dokumenti i elektronički dokumenti nabavljeni kupnjom ili pretplatom preko nacionalnog konzorcija.

Nabava se zbog toga razlikuje i prema vrsti građe pa knjižnice nabavljaju knjižnu i neknjižnu građu, elektroničku građu izravnog pristupa te e-izvore. Današnja politika izgradnje zbirki temelji se na analognim i digitalnim zbirkama, kao i daljinski dostupnim informacijskim izvorima te zbog toga danas knjižničnu zbirku predstavlja skup fizičkih izvora informacija združenih s virtualnim pristupom i organiziranim izvorima informacija. ${ }^{39}$

Upravljanje znanstvenim izvorima u različitim formatima jedna je od najvažnijih vrijednosti za buduće generacije i jedan od najozbiljnijih izazova s kojima smo suočeni. ${ }^{40}$

36 Usp. Clayton, P.; G. E.Gorman. Nav. dj., str. 52-72. Citirano prema: Siber, Lj.; S. Lukačević. Nav. dj., str. 82.

37 Usp. Corrall, S.; R. Angharad. Information resource development and "collection" in the digital age: conceptual frameworks and new definitions for the network world. // Changes in the world of electronic resources: Information and digitization, 20 June 2012 - 22 June 2012, Zadar, Croatia. [ citirano: 2020-07-30]. Dostupno na: http://d-scholarship.pitt.edu/25171/.

38 Usp. Gorman, M. Nav. dj., str. 459.

39 Golubović, V. Nabava knjižnične građe u funkciji izgradnje knjižnične zbirke. // HKD Novosti 76(2018) [citirano: 2020-08-20]. Dostupno na: https://www.hkdrustvo.hr/hkdnovosti/clanak/1449.

40 Usp. Horava,T. Nav. dj., str. 145. 


\section{Nabavna politika u visokoškolskim knjižnicama}

Visokoškolske knjižnice nisu više samo podrška izvedbenim planovima i programima nego postaju i ravnopravni suradnici u stjecanju i stvaranju znanja, promovirajući time promjene u sustavu visokog obrazovanja. ${ }^{41}$ Stručnom i planskom organizacijom knjižničnih zbirki, brzim i jednostavnim pristupom bazama podataka i ostalim izvorima informacija knjižnice osiguravaju kvalitetu akademskog i cjeloživotnog obrazovanja studenata i omogućavaju primjerene uvjete za znanstveni $i$ istraživački rad znanstveno-nastavnog osoblja.

$\mathrm{Na}$ tom tragu nabavna politika, između ostaloga, treba obuhvatiti skup konkretnih uputa o tome kakvim sadržajima i formalnim kriterijima knjižnica popunjava svoje zbirke i na koji način to realizira. ${ }^{42} \mathrm{Na}$ razini sveučilišta potrebno je usklađivati koordiniranu nabavu stručne i znanstvene literature interdiscplinarnog i multidisciplinarnog sadržaja, temeljnih znanstvenih djela, stranih časopisa i referentnih publikacija.

Sustavna nabavna politika omogućava racionalno trošenje proračunskih sredstava i zahtijeva od knjižničara stručne, organizacijske i menadžerske vještine. ${ }^{43}$ Prema Stouthuysenu, Swiggersu, Reheulu i Roodhooftu ${ }^{44}$ nabava knjižnične građe proces je stjecanja novih sadržaja koji uključuje odluku hoće li se određeni sadržaj kupiti ili ne, izbor dobavljača i administrativne poslove uključene u cjelokupan proces.

Svaka bi knjižnica trebala imati pisane smjernice kao temelj za izgradnju zbirki, prvenstveno zbog toga jer omogućavaju lakše planiranje istih, kao i selekciju u skladu s potrebama korisnika. Poštivanjem prihvaćenih smjernica kojima su utvrđeni kriteriji dosljednosti izgradnje knjižničnih zbirki osigurava se nabava raznovrsnih informacijskih izvora u okvirima zadanih mjerila kvalitete za određeno znanstveno i stručno područje. S druge strane transparentnim načelima i kriterijima na kojima se temelji izgradnja zbirki smjernice pružaju korisnicima uvid u to što mogu očekivati od knjižnične zbirke kako bi zadovoljili vlastite informacijske potrebe. Povjerenje korisnika u knjižničarev odabir, bez obzira na format ili vrstu izvora kojima pruža pristup, štedi vrijeme korisnika, zadržava njegovu pažnju i daje izravan pečat kvaliteti. ${ }^{45}$ Problem je kod visokoškolskih knjižnica u Hrvatskoj upravo nedostatak primjerenih smjernica za izgradnju i upravljanje zbirkama ${ }^{46}$, pa je to bilo i jedno od polazišta provedenog istraživanja.

${ }^{41}$ Usp. Krajna, T.; H. Markulin. Nav. dj., str. 22.

42 Usp. Leonhardt, T. Nav. dj. Citirano prema: Siber, Lj.; S. Lukačević. Nav. dj., str. 82.

43 Lewis, J. S. An assessment of publisher quality by political science librarians. // College \& Research Libraries 61, 4(2000), 313-323. Citirano prema: Siber, Lj.; S.Lukačević. Nav. dj., str. 86.

44 Usp. Stouthuysen, K.; M. Swiggers.; A. Reheul.; F.Roodhooft. Time-driven activity-based costing for a library acquisition process: a case study in a Belgian University. // Library Collections, Acquisitions, \& Technical Services 34, 2-3(2010), 83-91, DOI: 10.1080/14649055.2010.10766264.

45 Usp. Horava, T. Nav. dj. str. 145.

46 Usp. Krajna, T.; H. Markulin. Nav. dj., str. 25. 
Nabava knjižnične građe u visokoškolskim knjižnicama usmjerena ${ }^{47}$ je na poslanje ustanove/fakulteta kako bi se pokrila predmetna znanstvena i stručna područja, potrebe svih korisnika, znanstveno-nastavnog osoblja, studenata i stručnih suradnika, namjene zbirki kao što su zbirke ispitne (obvezne i dopunske) i seminarske literature za postojeće studijske programe unutar ustanove te znanstvena literatura za znanstvenoistraživački rad, kao i izgradnja posebnih zbirki. Spomenuti elementi utječu na veličinu zbirke te dostupnost, način uporabe i pohranu.

Najčešći je način nabave građe $u$ visokoškolskim knjižnicama kupnja koja poglavito ovisi o financijskim mogućnostima ustanove i izdvojenih sredstava za knjižnicu. ${ }^{48}$ Darovi i razmjena publikacija (pogotovo između srodnih fakulteta) još su uvijek jedan od najčešćih oblika nabave. Specifičan su oblik nabave u izgradnji knjižničnih zbirki fakultetska izdanja koja se izravno uvrštavaju u knjižnične zbirke.

Suradnjom među knjižnicama putem međuknjižnične posudbe izbjegavaju se preklapanja i usklađuju izvori i sredstva za nabavu prilikom planiranja razvoja zbirki. Posudba građe, plaćanjem usluge drugim knjižnicama na nacionalnoj i međunarodnoj razini, opravdana je kada osigurava izvore koji se trenutno ne mogu nabaviti iz više razloga, poput nedostatka financijskih sredstava, nepostojanja potrebnog izdanja na tržištu, zahtjevnijih korisnika i kratkoročnih potreba za nekim informacijskim izvorom.

Posljednjih godina velik utjecaj na izgradnju knjižnih zbirki u visokoškolskim knjižnicama ima koordinirana konzorcijska nabava preko nacionalne licence ${ }^{49}$ te primjena Conspectus-modela ${ }^{50}$ „kojim se utvrđuje snaga zbirke, što znači njezina kvaliteta s obzirom na njezinu svrhu i poslanje. Zbirka je vrijedna onoliko koliko odgovara pred nju postavljenim zahtjevima.“

\section{Istraživanje}

\subsection{Svrha, ciljevi i metodologija}

Istraživanje ima za svrhu utvrditi, usporediti i skrenuti pozornost na najznačajnije čimbenike koji utječu na promjene u podizanju kvalitete knjižničnih zbirki,

47 Usp. isto, str. 25.

48 Zadnjih godina zbog postupka vanjskog vrednovanja visokoškolskih ustanova, unutar kojeg se vrednuje i knjižnica, mijenja se odnos uprave sveučilišta/fakulteta/odjela prema izdvajanju financijskih sredstava za nabavu knjižnične građe.

49 Od 2016. godine preko projekta Povećanje pristupa elektroničkim izvorima znanstvenih $i$ stručnih informacija, skraćenoga naziva e-Izvor, osigurana su financijska sredstva iz Europskog socijalnog fonda za nabavu elektroničkih i stručnih informacija iz svih područja znanosti. Usp. Projekt e-Izvori. [citirano: 2020-08-30. ]. Dostupno na: http://baze.nsk.hr/projekt-e-izvori/

50 Usp. Leščić, J.; Z. Majstorović. Nav. dj., str. 289. 
utvrditi provodi li se kontinuirana i sustavna nabavna politika u njihovoj izgradnji i koliko matična ustanova u knjižnicama sastavnicama Sveučilišta u Osijeku utječe na donošenje odluka u upravljanju zbirkama te koji je najbolji način njihova rješavanja.

Iz tako postavljene svrhe proizlaze i ciljevi i istraživačka pitanja. Jedan je od ciljeva utvrditi stanje i promjene u nabavnoj politici i izgradnji knjižničnih zbirki u visokoškolskim knjižnicama sastavnicama ${ }^{51}$ Sveučilišta Josipa Jurja Strossmayera u Osijeku ${ }^{52}$ temeljom longitudinalnog istraživanja provedenog tijekom ožujka 2015. i ožujka 2019. godine.

Nadalje istraživanjem se nastoji utvrditi na koji se način provodi nabava prema vrsti građe i obliku nabave, ima li značajnijih promjena u izgradnji knjižničnih zbirki u promatranom razdoblju te postoje li pisani dokumenti fakulteta i knjižnice kojima je uređena nabava i izgradnja knjižničnih zbirki.

Polazna osnova istraživanja pretpostavka je da koordinirana izgradnja i upravljanje knjižničnim zbirkama pridonosi racionalizaciji troškova i transparentnom provođenju nabavne politike temeljom utvrđenih smjernica te kvalitetnijoj suradnji s matičnom Gradskom i sveučilišnom knjižnicom Osijek i drugim visokoškolskim knjižnicama u sastavu Sveučilišta u Osijeku, kao i jačanju suradnje na nacionalnoj razini.

Istraživanje je provedeno uz pomoć online anketnog upitnika. Anketni se upitnik sastojao od 38 pitanja (pitanja s višestrukim odgovorima i otvorena pitanja) podijeljenih u tri skupine. U prvom su dijelu upitnika ispitanici odgovarali na opća demografska pitanja (npr. radni staž, zvanje). Druga skupina pitanja imala je za cilj dobiti odgovore na pitanja vezana uz vrste knjižničnih zbirki u drugim visokoškolskim knjižnicama u sastavu Sveučilišta u Osijeku. Posljednja, treća skupina pitanja odnosila se na nabavnu politiku (npr. postoje li pisani dokumenti o nabavi knjižnične građe, kao i plan nabave te unaprijed određeni proračun za nabavu, način donošenja odluka o nabavi i sam proces nabave, način nabave, način pročišćavanja i vrednovanja knjižničnih zbirki).

Zamolba za ispunjavanje upitnika, koji je bio dostupan putem poveznice, dostavljena je elektroničkim putem voditeljima visokoškolskih knjižnica. U istraživanju je uporabljen prigodni uzorak. U istraživanju 2015. godine sudjelovalo je 13 voditelja visokoškolskih knjižnica Sveučilišta u Osijeku ${ }^{53}$, uključujući Knjižnicu

51 Sastavnice Sveučilišta Josipa Jurja Strossmayera u Osijeku [citirano: 2020-08-11] Dostupno na: http://www.unios.hr/o-sveucilistu/sastavnice/

52 U daljnjem tekstu koristit će se naziv Sveučilište u Osijeku.

${ }^{53}$ Autorice su istraživanje najavile na sastanku voditelja knjižnica sastavnica Sveučilišta J.J. Strossmayera, koji se održavaju redovito pri Matičnoj službi Gradske i sveučilišne knjižnice Osijek, koja je ujedno i matična knjižnica za Veleučilište u Požegi, Slavonskom Brodu i Veleučilište 
Kliničkog bolničkog centra u Osijeku ${ }^{54}$, Knjižnicu Veleučilišta u Požegi ${ }^{55}$ i Veleučilišta Lavoslav Ružička u Vukovaru ${ }^{56}$, a 2019. godine 15 voditelja visokoškolskih knjižnica ${ }^{57}$, uključujući i Knjižnicu Veleučilišta u Slavonskom Brodu ${ }^{58}$ koja nije obuhvaćena prethodnim istraživanjem.

Podaci dobiveni iz anketnih upitnika uzeti su kao osnova za provedbu polustrukturiranih intervjua kako bi se dodatno istražila sljedeća područja: sadržaj pisanih dokumenata matične ustanove i knjižnice vezano uz nabavu knjižnične građe, smjernice za nabavu knjižnične građe te vrednovanje knjižničnih usluga.

Intervjuirano je 5 voditelja visokoškolskih knjižnica koji su sudjelovali i u kvantitativnom dijelu istraživanja. Izabrani su metodom prigodnog uzorka prema znanstvenim područjima i to za prirodne znanosti (ispitanik M4), tehničke znanosti (ispitanici Z2 i V5), humanističke i društvene znanosti (ispitanik J6) i biotehničke znanosti (ispitanik S1) te jedan djelatnik Službe nabave Gradske i sveučilišne knjižnice (ispitanik S3) koji je ujedno i predstavnik Matične službe za visokoškolske i specijalne knjižnice.

Intervjui su provedeni putem telefona, snimljeni su, a podatci su transkribirani, kodirani i analizirani. Sadržajna analiza napravljena je ručno.

\subsection{Rezultati}

\subsubsection{Opći podaci o ispitanicima}

Ispitanici istraživanja bili su voditelji visokoškolskih knjižnica Sveučilišta u Osijeku.

Lavoslav Ružička u Vukovaru. Voditeljice knjižnica navedenih veleučilišta izrazile su želju da bi sudjelovale u istraživanju. Prema podatcima Sveučilište J. J. Strossmayera u Osijeku ima 25 sastavnica, od kojih je 12 fakulteta, jedna akademija i četiri odjela koji imaju knjižnice u sastavu. Ostale sastavnice, njih sedam, nemaju knjižnicu i nisu bile predmet istraživanja, kao ni Gradska i sveučilišna knjižnica Osijek.

54 Knjižnica Kliničkog bolničkog centra u Osijeku. [citirano: 2020-08-11]. Dostupno na: http:// www.kbco.hr/znanost/knjiznica/

55 Knjižnica Veleučilišta u Požegi. [citirano: 2020-08-11]. Dostupno na: https://www.vup.hr/o_ nama/sluzbe/knjiznica/default.aspx

56 Knjižnica Veleučilišta Lavoslav Ružička u Vukovaru. [citirano: 2020-08-11]. Dostupno na: https://www.vevu.hr/?i=138

57 U istraživanju 2019. godine sudjelovali su isti ispitanici, njih 13 anketiranih 2015. godine te Fakultet za dentalnu medicinu i zdravstvo koji je osnovan 2017. godine.

58 Knjižnica Veleučilišta u Slavonskom Brodu. U međuvremenu, od 3. kolovoza 2020. godine Veleučilište dobiva status Sveučilišta. [citirano: 2020-08-11]. Dostupno na: https://www.unisb.hr/ 
Na pitanje o radnom vijeku najveći broj ispitanika u 2015. godini odgovorio je da se kreće između 5 i 15 godina (njih 8), a u 2019. godini najveći broj ispitanika imao je između 16 i 20 godina (5 ispitanika) i između 5 i 15 godina radnog staža (4 ispitanika).

S obzirom na stručno zvanje, 2015. godine većina je ispitanika označila da ima zvanje diplomiranog knjižničara, njih 11, a zvanje višeg knjižničara 2 ispitanika. U 2019. godini također je većina ispitanika označila da ima zvanje diplomiranog knjižničara ( 9 ispitanika). Zvanje višeg knjižničara odabralo je 4 ispitanika, a knjižničarskog savjetnika 2 ispitanika. ${ }^{59}$

\subsubsection{Vrste knjižničnih zbirki}

U prvom su pitanju drugog dijela upitnika, koji se odnosi na vrste knjižničnih zbirki, ispitanici trebali označiti koje sve zbirke posjeduje njihova knjižnica. Dobiveni rezultati, kao što se može iščitati iz slike 1 ., u oba promatrana razdoblja upućuju na određene promjene. Sve knjižnice posjeduju zbirku monografskih publikacija (2015. 13, a 2019. 15 knjižnica), velika većina posjeduje referentnu zbirku (2015. 12, a 2019. 14), zbirku periodike (2015. 12, a 2019. 13) i zbirku doktorskih disertacija (2015. 10, a 2019. 12) te zbirku studentskih ocjenskih radova, odnosno diplomskih (2015. 8, a 2019. 10 ) i završnih radova (2015. 8, a 2019. 11).

U jednoj od knjižnica posebno je izdvojena Zbirka Europskog dokumentacijskog centra i Zbirka službenih publikacija, a u drugoj Zbirka snimaka studentskih ispita i Zbirka muzikalija. U 2019. godini značajno je smanjeno financiranje online baza podataka vlastitim sredstvima, što se očituje i u dobivenim rezultatima (4 ispitanika), a u odnosu na 2015. godinu (7 ispitanika). Institucijski repozitorij prilikom istraživanja u 2015. godini imala je samo jedna knjižnica, dok u 2019. imaju sve (15 knjižnica) s obzirom na obvezu temeljom zakonodavne osnove. ${ }^{60}$ Nadalje, u 2019. godini posebno su izdvojene zbirke specijalističkih završnih radova (9 knjižnica) stečene na specijalističkim studijima u skladu s promjenama zakonske regulative. ${ }^{61}$

\footnotetext{
59 Većina ispitanika sudjelovala je $u$ oba istraživanja pa je to pokazatelj i njihova napredovanja $u$ stručnom zvanju. Manji broj ispitanika nije sudjelovao u oba istraživanja.

60 Zakon o znanstvenoj djelatnosti i visokom obrazovanju: pročišćeni tekst zakona: Narodne novine 123/2003, 198/2003, 105/2004, 174/2004, 2/2007, 46/2007, 45/2009, 45/2009, 63/2011, 94/2013, 139/2013, 101/2014, 60/2015, 131/2017 i 96/2018. // Zakon.hr. [citirano: 2019-08 18]. Dostupno na: https://www.zakon.hr/z/320/Zakon-o-znanstvenoj-djelatnosti-i-visokom-obrazovanju

61 Usp., isto.
} 


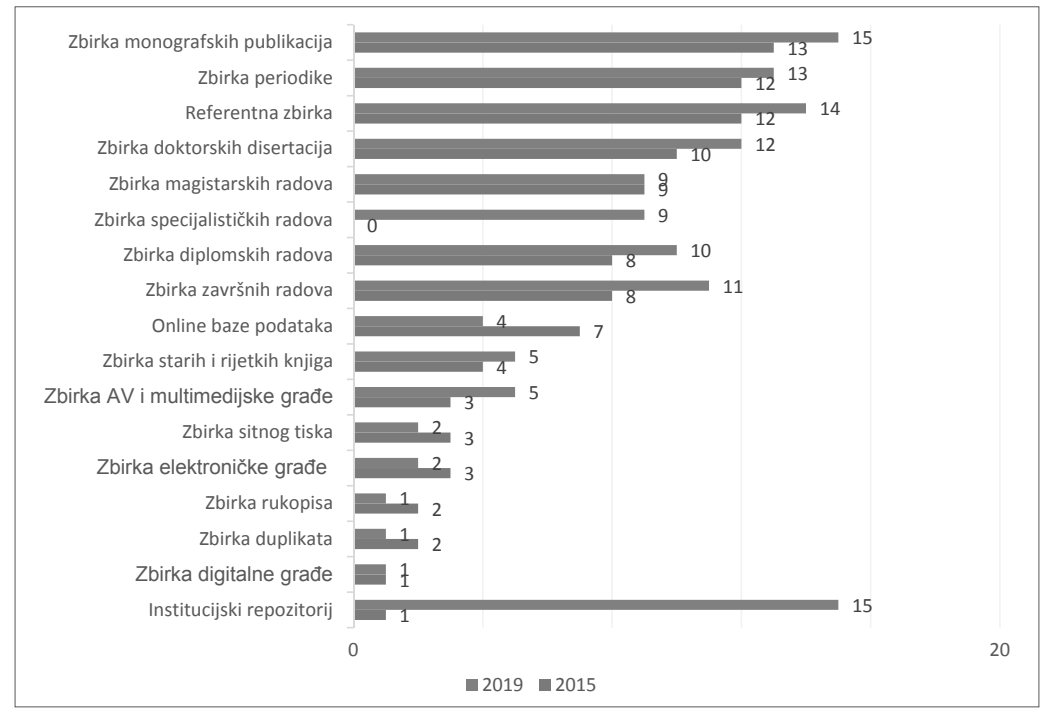

Slika 1. Vrste knjižničnih zbirki

\subsubsection{Nabavna politika}

U ovom su dijelu upitnika ispitanici trebali navesti pisane dokumente matične ustanove u kojima se pojavljuje pojam nabava knjižnične građe. U većem broju knjižnica nabava knjižnične građe kao pojam pojavljuje se u godišnjem proračunu matične ustanove u oba promatrana razdoblja (2015. 7, a 2019. 9). Dok u 2015. godini samo dvoje ispitanika navodi poslanje kao dokument u kojem se pojavljuje nabava knjižnične građe kao pojam, u 2019. godini nijedan ispitanik nije označio navedeni dokument (slika 2.).

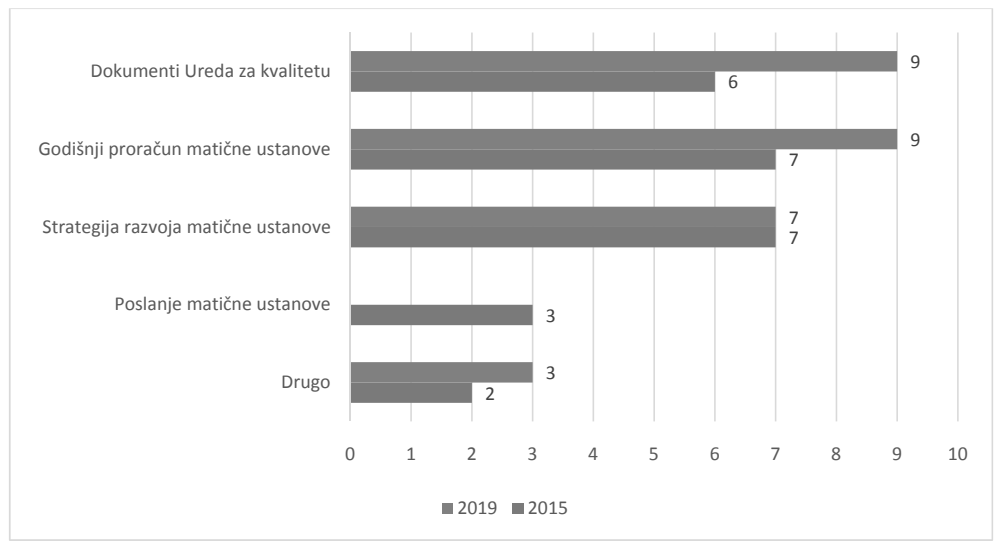

Slika 2. Pisani dokumenti matične ustanove u kojima se pojavljuje pojam nabava knjižnične građe 
Zatim nas je zanimalo u kojim pisanim dokumentima pojedina knjižnica definira nabavu knjižnične građe. U oba promatrana razdoblja većina ispitanika navela je da nabavu knjižnične građe definiraju u Pravilniku o radu knjižnice (2015. 12, a 2019. 15). Smjernice za nabavu građe ima manji broj knjižnica. Naime prema podatcima u 2015. godini samo tri knjižnice, a u 2019. godini četiri knjižnice (slika 3.).

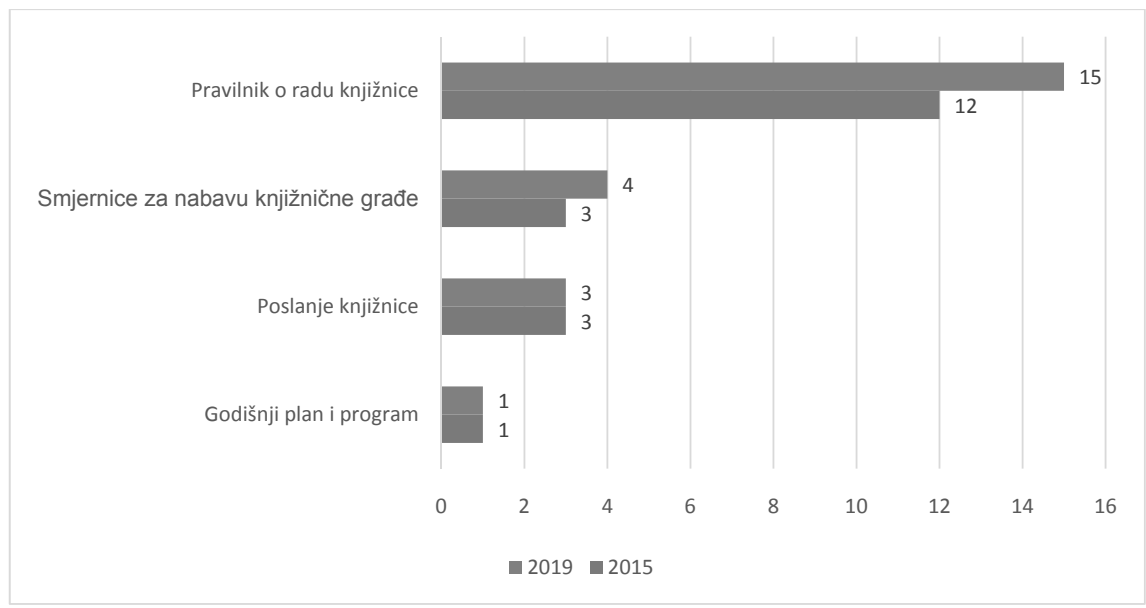

Slika 3. Pisani dokumenti knjižnice u kojima se definira nabava knjižnične građe

U sljedećem su pitanju ispitanici trebali navesti izrađuju li pisani plan nabave knjižnične građe. U 2015. godini 6 ispitanika odgovorilo je pozitivno, dok je u 2019. godini taj broj nešto manji (5 knjižnica). U 2015. godini jedan ispitanik izjavio je da su ,,izradili detaljan pregled postojećeg stanja udžbenika prema izvedbenim planovima nastave i u odnosu na potreban broj prema knjižničnim standardima“, a drugi da su pisani plan nabave izradili ,sa studentima kroz pilot-projekt“". Nadalje, kao jedan vid planiranja nabave, u 2019. godini jedan ispitanik navodi „izvješće Knjižničnog odbora“, a drugi zahtjev nastavnika „za nabavom određenih naslova vezano za obaveznu i dopunsku literaturu“.

Što se godišnjeg proračuna tiče, u oba promatrana razdoblja 7 ispitanika navodi da za nabavu knjižnične građe imaju unaprijed određeni godišnji proračun.

Potom, odgovarajući na pitanje o izvorima financijskih sredstava za kupnju knjižnične građe (slika 4.), svi su ispitanici u oba promatrana razdoblja označili matičnu ustanovu (2015. njih 13, a 2019. njih 15) kao glavni izvor financiranja, a najmanje ispitanika (2015. 6, a 2019. 5) navodi Ministarstvo znanosti i obrazovanja. Također značajan dio nabave knjižnične građe čini nabava putem sudjelovanja u znanstvenim projektima (u 2015. i u 2019. - to je izdvojilo 9 ispitanika). Zanimljivo je da u 2019. godini ispitanici navode razmjenu kao izvor financijskih 
sredstava (njih 8). Navedeni način nabave očito predstavlja sve češći način dolaženja do potrebnih naslova, a s druge strane predstavlja novčanu uštedu jer knjižnice između sebe razmjenjuju vlastita izdanja.

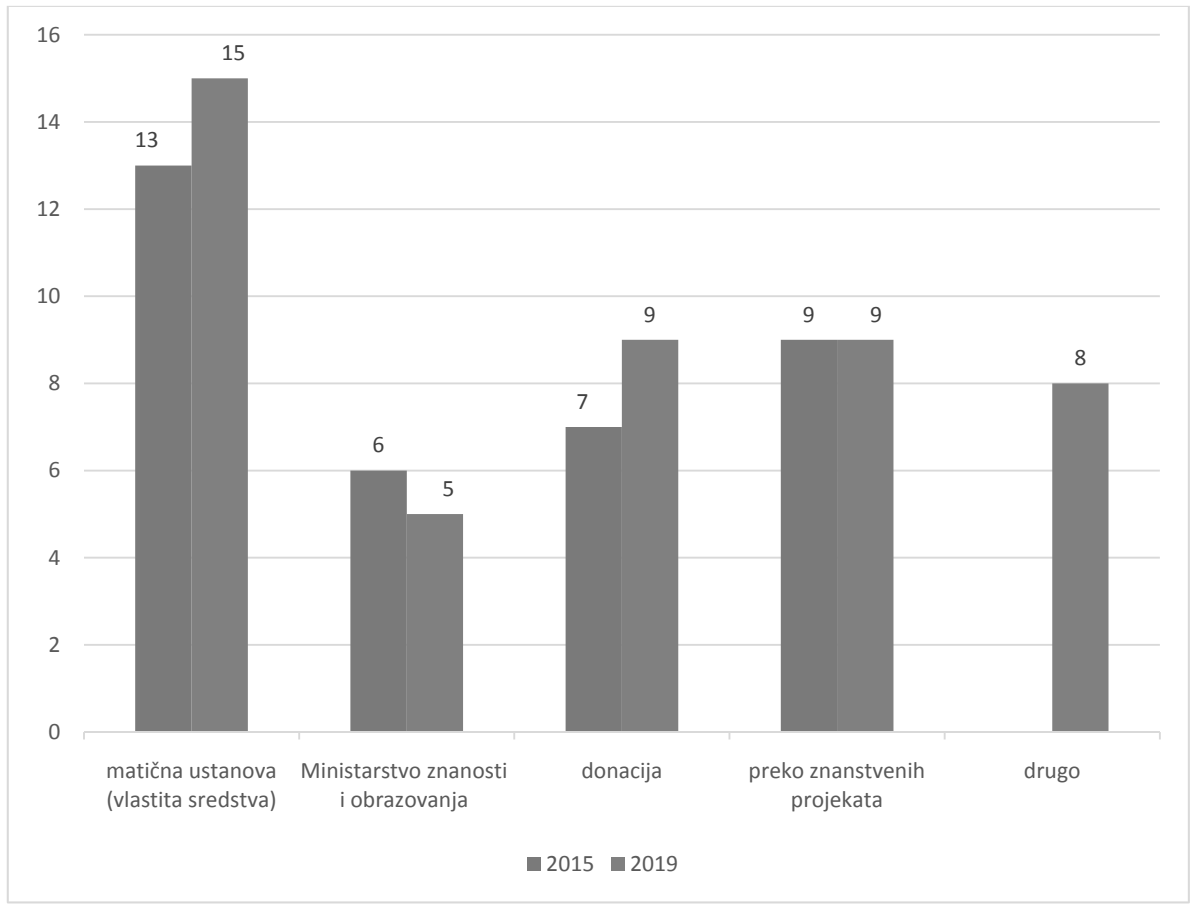

Slika 4. Izvori financijskih sredstava za nabavu knjižnične građe

Autorice je posebno zanimao način na koji knjižnice donose odluke o nabavi knjižnične građe u odnosu na samostalnost voditelja pri donošenju odluke i predlaganju nabave. Iz slike 5. vidljivo je da u najvećem broju knjižnica odluku o nabavi donosi isključivo dekan fakulteta na temelju prijedloga voditelja knjižnice (i 2015. i 2019. 10) i nastavnog osoblja (i 2015. i 2019. 8), ali i voditelj knjižnice u dogovoru s nastavnim osobljem (2015. 7, a 2019. 9).

Najmanji broj knjižnica (2015. njih 3, a 2019. 2) ima povlasticu da samostalno odlučuje o nabavi. Treba istaknuti da raste broj knjižnica u kojima korisnici izravno predlažu nabavu. Naime u sve većem broju knjižnica voditelji konzultiraju studente i predlažu nabavu na temelju baze desiderata (2015. 3, a 2019. 6). Vidljiv je porast praćenja izvedbenih planova nastave od strane voditelja knjižnica i usklađivanje knjižničnih zbirki prema literaturi navedenoj u njima (2015. 4, a 2019. 8).

Uloga knjižničnih odbora u nabavi prisutna je samo u nekoliko knjižnica (2015. u dvije knjižnice, a 2019. u tri). 


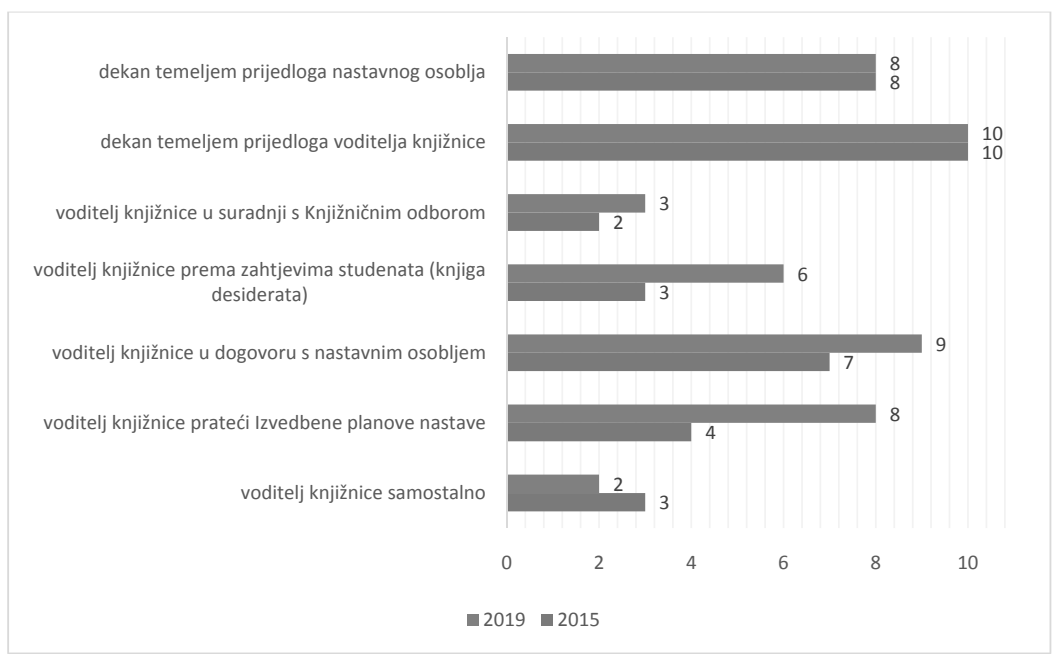

Slika 5. Način na koji knjižnica donosi odluku o kupnji knjižnične građe

Kao što se iz slike 6. može iščitati, način je nabave knjižnične građe uobičajen. Svi ispitanici u oba promatrana razdoblja izjavili su da knjižničnu građu nabavljaju kupnjom, darom i kroz vlastita izdanja (2015. 13, a 2019. 15). No vidljivo je da visokoškolske knjižnice s obzirom na zahtjeve korisnika knjižničnu građu većim dijelom nabavljaju i razmjenom $(2015.11,2019.11)$ te međuknjižničnom posudbom (2015. njih 9, a 2019. 11), ali i preko znanstvenih projekata (2015. 8, 2019. 9). U oba promatrana razdoblja koordinirana nabava najrjeđi je oblik nabave (2015. 1, a 2019. 1).

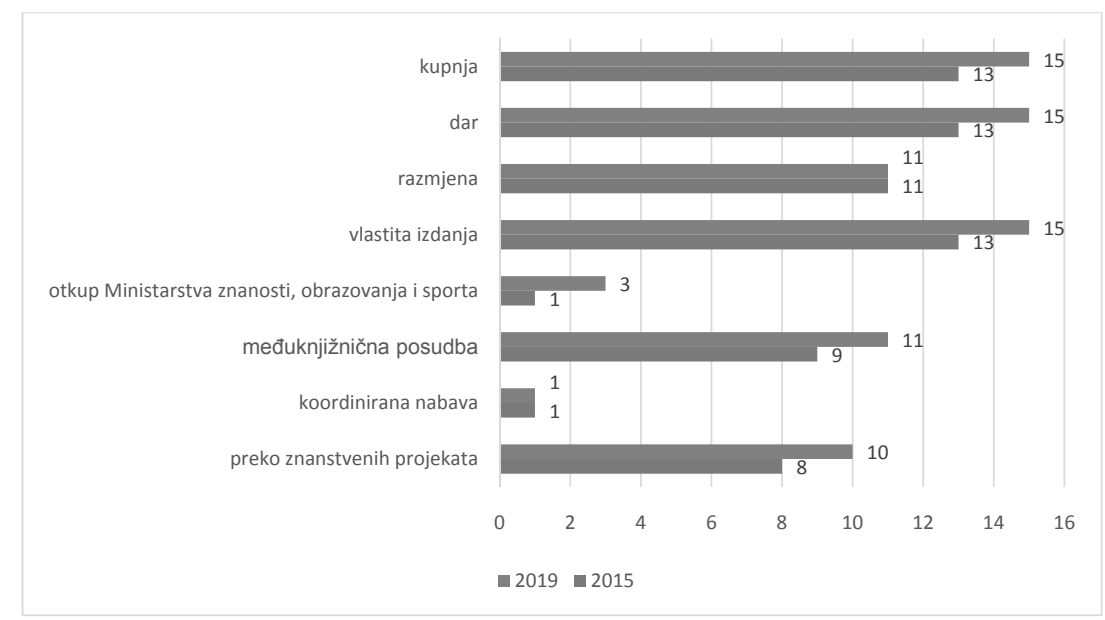

Slika 6. Način nabave knjižnične građe 
Specifičnost visokoškolskih knjižnica način je nabave prema vrsti građe vezane uz pojedine kolegije: obvezna, dopunska i seminarska literatura, kao i literatura za znanstvenoistraživački rad. Ispitanici su trebali procijeniti u kojoj mjeri njihova knjižnica nabavlja navedenu vrstu građe (pri čemu je 1 - najrjeđe, a 5 - najčešće).

Dok u 2015. godini nešto manje od polovine ispitanika najčešće nabavlja obveznu literaturu (njih 6), u 2019. godini navedenu vrstu građe nabavlja većina ispitanika (12 ispitanika). Što se tiče nabave literature za potrebe pisanja studentskih radova, primjećuje se blagi porast u odnosu na prvo promatrano razdoblje. Naime dok je u 2015. godini nešto manje od trećine ispitanika često nabavljalo tu vrstu građe (njih 4), u 2019. godini gotovo polovina ispitanika navodi da često nabavlja seminarsku literaturu (7 ispitanika).

Nadalje u 2019. godini primijećen je pad u nabavi literature za znanstvenoistraživački rad (samo 1 ispitanik) u odnosu na 2015. godinu (5 ispitanika). Blagi pad također se primjećuje i u nabavi referentne građe, što se može objasniti sve većom uporabom te vrste građe u digitalnom obliku i kao takve dostupne na internetu. Naime dok u 2015. godini više od polovine ispitanika navodi da često nabavlja referentnu građu (7 ispitanika), u 2019. godini taj se broj smanjuje (njih 3).

U oba promatrana razdoblja nema većih odstupanja u kupnji domaćih tiskanih izdanja. Knjižnice domaća tiskana izdanja gotovo podjednako kupuju i od izdavača (2015. 13, a 2019. 12) i od dobavljača (2015. 13, a 2019. 13). Većina knjižnica inozemna tiskana izdanja kupuje preko domaćeg dobavljača (2015. 11 knjižnica, a 2019. njih 13), a manje izravno od izdavača (2015. 6, a 2019. 3).

Većina ispitanika izjavila je da dobiva izdanja fakulteta besplatno (2015. 12, a 2019. 14) i to određeni broj primjeraka, što je kod većine uređeno Pravilnikom o izdavačkoj djelatnosti (2015. 9, a 2019. 11). Samo jedna knjižnica kupuje vlastita izdanja udžbenika i dopunske literature, no na dar prima časopis i zbornike s konferencija u izdanju Fakulteta.

Također većina knjižnica knjižničnu građu u izdanju matične ustanove rabi za potrebe razmjene (2015. 10, a 2019. 12).

Na pitanje vezano uz selekciju darovane građe, većina ispitanika izjavila je da njihova knjižnica zadržava pravo na selekciju (2015. 11, a 2019. 14 ispitanika). Darovanu građu koju ne zadržavaju u knjižnici najčešće daruju drugim knjižnicama (2015. 10, a 2019. 9), korisnicima (2015. 8, a 2019. 9) ili rabe za potrebe razmjene (2015. 4, a 2019. 4).

Potom nas je zanimalo koju vrstu elektroničke građe ispitanici nabavljaju kupnjom (slika 7.). Vidljiv je porast pretplate na elektroničke knjige u drugom promatranom razdoblju (2015. 2, a 2019. 6).

Nadalje u oba promatrana razdoblja vidljivo je da je dio ispitanika izjavio da ne kupuje elektroničku građu (2015. 5, a 2019. 7 ispitanika). U 2019. godini smanjila se i kupnja baza podataka vlastitim sredstvima (2015. 3, a 2019. 2), što je, prema izjavama ispitanika, posljedica povećane dostupnosti elektroničkih izvora putem nacionalne licence od 2016. godine. 


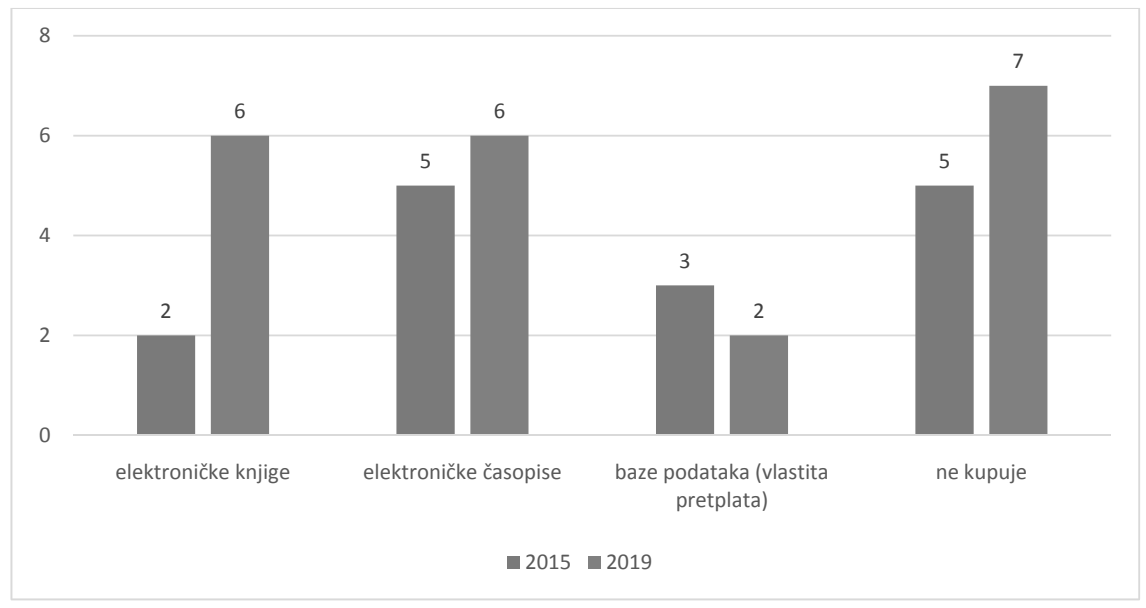

Slika 7. Nabava elektroničke građe

Većina ispitanika na pitanje o pročišćavanju knjižničnog fonda izjavila je da ga provode kroz otpis (2015. 9, a 2019. 12 ispitanika) i reviziju (2015. 9, a 2019. 13), dok vrlo mali broj ispitanika nije imao tu potrebu (2015. 2, a 2019. 1). Radi se o knjižnicama koje su nastale odvajanjem fakulteta pa nemaju potrebe pročišćavati knjižnični fond, a nisu ni zakonski obvezne na to (slika 8).

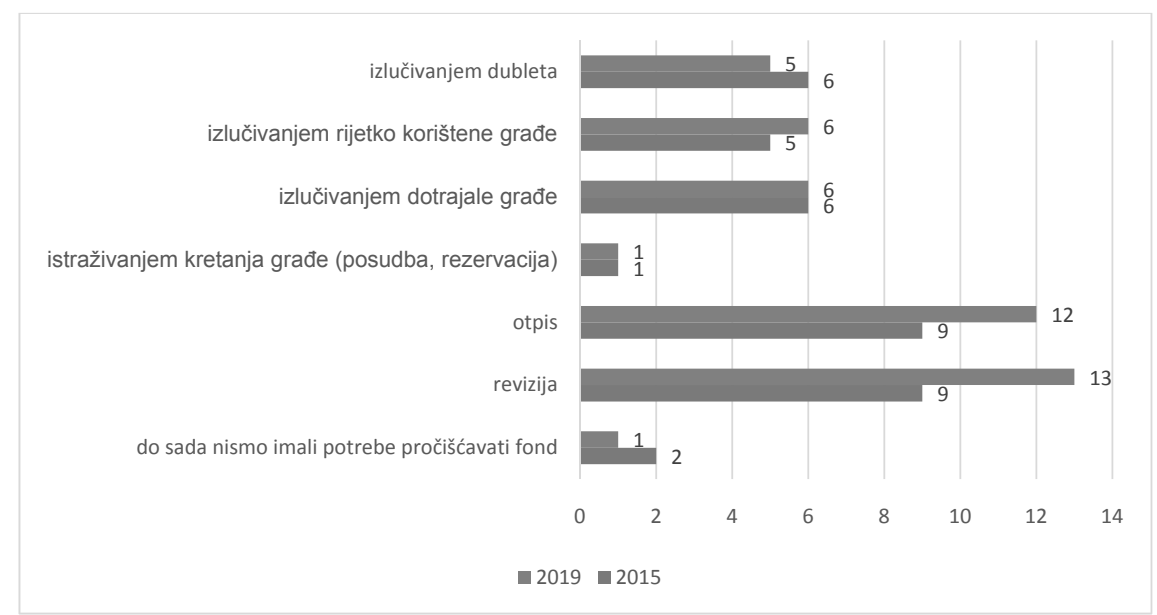

Slika 8. Pročišćavanje knjižničnog fonda

Odgovarajući na pitanje o načinima vrednovanja nabavljene knjižnične građe, u 2015. godini najveći broj ispitanika odgovorio je kroz povratne informacije korisnika (njih 12), dok se u 2019. godini taj broj smanjuje (9 ispitanika). 
Povećao se broj ispitanika koji provjeravaju pokrivenost predmetnih područja prema izvedbenim planovima nastave (njih 13), za razliku od 2015. godine gdje je taj broj manji (8 ispitanika).

Nadalje dok u 2019. godini gotovo polovina ispitanika navodi kvantitativne statističke podatke o učestalosti uporabe (6 ispitanika), a petina ispitanika citatnu analizu studentskih ocjenskih radova (3 ispitanika), u 2015. godini nijedan ispitanik ne navodi nijedan od tih dvaju načina vrednovanja knjižnične građe (slika 9).

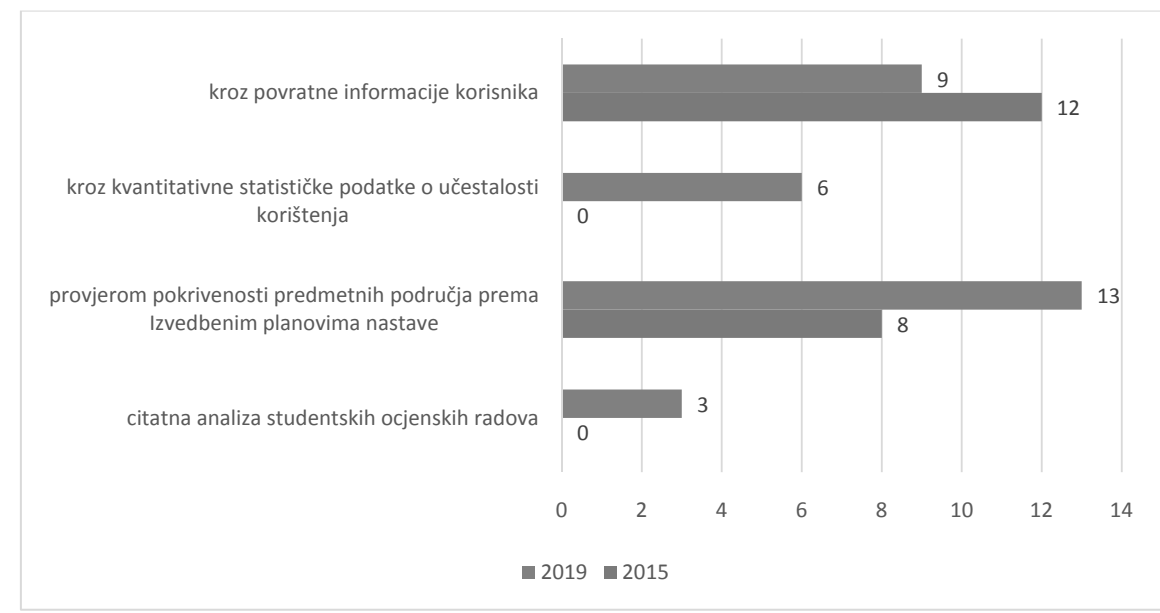

Slika 9. Način vrednovanja nabavljene knjižnične građe

\section{Rezultati provedenih intervjua}

U intervju s ispitanicima pokušali smo saznati što donosi sadržaj tih dokumenata vezano uz nabavu knjižnične građe, jesu li javno dostupni te mogu li dati poveznicu s dokumentom matične ustanove. Većina voditelja navodi samo dokument, najčešće Pravilnik o radu knjižnice (ispitanik S1, Z2, M4), ali ne i što donosi sadržaj navedenih dokumenata vezano uz nabavu knjižnične građe. Dok je jedan od ispitanika odgovorio da se $u$ dokumentima matične ustanove ne navodi nabava knjižnične građe (ispitanik J6), drugi ispitanik (ispitanik S3) navodi sljedeće dokumente javno dostupne u kojima se spominje nabava knjižnične građe: Statut Gradske i sveučilišne knjižnice Osijek ${ }^{62}$, Program rada knjižnične djelatnosti kroz godine, zadnji za 2020. godinu ${ }^{63}$, financijski planovi i odluke o prihvaćanju kroz

62 Statut Gradske i sveučilišne knjižnice Osijek. [citirano: 2020-10-16]. Dostupno na: https:// www.gskos.unios.hr/wp-content/uploads/2017/02/STATUT.pdf

63 Program rada knjižnične djelatnosti Gradske i sveučilišne knjižnice Osijek za 2020 godinu. [citirano: 2020-10-16]. Dostupno na: https://www.gskos.unios.hr/wp-content/uploads/2019/12/ Program-rada-2020..pdf 
godine, zadnji 2020. godine ${ }^{64}$, izvješća o radu kroz godine, zadnje 2019. godine ${ }^{65}$, Plan i program Službe nabave kroz godine, Smjernice za nabavu ${ }^{66}$, Smjernice za postupak pri darivanju građe ${ }^{67}$ i Kriterije i metode vrednovanja AV-građe i multimedije u narodnim knjižnicama ${ }^{68}$. Dok se u većini navedenih dokumenata nabava knjižnične građe pojavljuje samo kao pojam, u Programu knjižnične djelatnosti za 2020. godinu detaljno se navodi na koji će način Gradska i sveučilišna knjižnica Osijek nastaviti popunjavati svoje zbirke i kroz koje načine nabave te za koje korisničke skupine, a s obzirom na svoju dvojnu funkciju, gradsku i sveučilišnu djelatnost. Također u Smjernicama za nabavu navode se i dokumenti s čijim je preporukama usklađena nabavna politika ustanove, načini nabave, vrste građe koja se nabavlja te kriteriji za nabavu knjižnične građe.

Svi intervjuirani voditelji navode Pravilnik o radu knjižnice kao dokument u kojem njihova knjižnica definira nabavu knjižnične građe (ispitanik S1, Z2, M4, V5 i J6). Dok je kod većine ispitanika Pravilnik o radu knjižnice javno dostupan (ispitanik S1, Z2, S3, M4 i J6), jedan ispitanik navodi da se navedeni dokument nalazi na intranetu ustanove (ispitanik V5) te je dostupan samo djelatnicima ustanove.

Neke od knjižnica u Pravilniku o radu knjižnice navode da knjižnična djelatnost, između ostalog, obuhvaća i nabavu knjižnične građe (ispitanik S1, M4, J6). Međutim sadržaj se tih dokumenata razlikuje. Kod nekih knjižnica glavne smjernice nabavne politike predlaže knjižnični odbor (ispitanik S1 ${ }^{69}, \mathrm{M} 4^{70}$ ), dok kod drugih knjižnični odbor predlaže dekanu nabavu inozemne i domaće literature (ispitanik S1), ali prema izvedbenom planu i studijskom programu (ispitanik Z2), iako se u Pravilniku o radu knjižnice navodi da knjižnica ima i knjižnični od-

${ }^{64}$ Financijski planovi i odluke o prihvaćanju za 2020. [citirano: 2020-10-16]. Dostupno na: https://www.gskos.unios.hr/wp-content/uploads/2019/12/odluka-4-javna-nabava.pdf

65 Izvješće o radu Gradske i sveučilišne knjižnice Osijek za 2019. [citirano: 2020-10-16]. Dostupno na: https://www.gskos.unios.hr/wp-content/uploads/2020/05/gisko2019-1205-compressed.pdf

${ }_{66}$ Smjernice za nabavu Gradske i sveučilišne knjižnice Osijek, Služba nabave. [citirano: 202010-16]. Dostupno na: https://www.gskos.unios.hr/wp-content/uploads/2017/03/Smjernice-za-nabavu-GISKO1.pdf

${ }_{67}$ Smjernice za postupak pri darivanju građe Gradske i sveučilišne knjižnice Osijek. [citirano: 2020-10-16]. Dostupno na: https://www.gskos.unios.hr/wp-content/uploads/2017/03/Smjernice-za-postupak-pri-darivanju-gradje-GISKO1.pdf

${ }_{68}$ Kriteriji i metode vrednovanja AV-građe i multimedije u narodnim knjižnicama: pregled. [citirano: 2020-10-16]. Dostupno na: https://www.gskos.unios.hr/wp-content/uploads/2017/03/Kriteriji-i-metode-vrednovanja-AV-grade-i-multimedije.pdf

${ }_{69}$ Pravilnik o radu Knjižnice. [citirano: 2020-10-17]. Dostupno na: http://www.ptfos.unios.hr/ images/dokumenti/na-razini-fakulteta/pravilnik-o-radu-knjiznice.pdf;

70 Pravilnik o radu Knjižnice Odjela za matematiku. [citirano: 2020-10-17]. Dostupno na: https:// www.mathos.unios.hr/images/homepages/bgrasa/Pravilnik_o_radu_knjiznice_Odjela_za_matematiku.pdf 
bor („financijsko-nabavnu politiku za knjižničnu građu vodi pročelnik Odjela”) ${ }^{71}$ (ispitanik M4). Ono što je zanimljivo jest da jedna od knjižnica u Pravilniku o radu knjižnice ne navodi knjižnični odbor, ${ }^{72}$ a knjižničnu građu nabavlja knjižnica „sukladno studijskim programima i izvedbenim planovima nastave pojedinih studija“"73 (ispitanik J6).

Ispitanicima je postavljeno i pitanje smatraju li da bi smjernice svake sastavnice trebale biti usklađene sa Smjernicama Gradske i sveučilišne knjižnice Osijek, na što je dio ispitanika odgovorio negativno (ispitanici S1, Z2 i M4), a dio smatra da bi to bilo dobro, ali da je u praksi teško izvedivo zbog toga što svaka sastavnica ima različit pristup nabavnoj politici (ispitanici V5 i J6). Jedan ispitanik smatra da su smjernice svake sastavnice, s obzirom na to da je Gradska i sveučilišna knjižnica Osijek knjižnica s dvojnom funkcijom, usklađene „u nekim osnovnim načelima“, ali mogu biti „različite u dijelu nabavnih sadržajnih politika svake pojedinačne sastavnice" (ispitanik S3). Na pitanje jesu li zainteresirani za radionicu za izradu smjernica za nabavu knjižnične građe koja bi im pomogla pri izradi vlastitih ili revidiranju postojećih u koordinaciji s Matičnom službom za visokoškolske i specijalne knjižnice veći broj ispitanika odgovorio je pozitivno (ispitanici S1, S3 i J6), ali pod uvjetom da se donese odluka na razini Sveučilišta (ispitanik V5), a manji broj negativno (ispitanici Z2 i M4).

Većina ispitanika u intervju (ispitanik S1, S3, M4, V5 i J6) navodi da se povratne informacije korisnika prikupljaju tijekom svakodnevnog rada s korisnicima (pri posudbi ili vraćanju knjižnične građe) kada korisnici daju povratnu informaciju posjeduje li njihova knjižnica građu koja im je potrebna ili ne. Također i vrednovanjem knjižničnih zbirki u okviru istraživanja o zadovoljstvu korisnika uslugama koje nudi njihova knjižnica, a provodi se svake tri godine. Taj način vrednovanja u intervjuu navodi samo 1 ispitanik (J6).

\section{Rasprava}

U radu su predstavljeni rezultati istraživanja čiji je cilj bio utvrditi način provođenja nabave prema vrsti građe i obliku nabave, promjene u izgradnji knjižničnih

\footnotetext{
71 Usp. isto

72 Prema novom Zakonu o knjižnicama (Usp. Zakon o knjižnicama i knjižničnoj djelatnosti. // Narodne novine 17, 356(2019). [citirano:2020-11-05]. Dostupno na: https://narodne-novine. nn.hr/clanci/sluzbeni/2019_02_17_356.html) više nije obaveza osnovati knjižnični odbor. Bez obzira na to, Rektorski zbor Sveučilišta obvezao je na neki način fakultete da i dalje zadrže knjižnične odbore kako je bilo propisano starim zakonom. Usp. Zakon o knjižnicama. // Narodne novine 105, 1616(1997). [citirano: 2019-08 18]. Dostupno na: https://narodne-novine.nn.hr/clanci/ sluzbeni/1997_10_105_1616.html.

${ }^{73}$ Pravilnik o radu Knjižnice Fakulteta za odgojne i obrazovne znanosti. [citirano: 2020-10-17]. Dostupno na: https://www.foozos.hr/dokumenti/knjiznica/Pravilnik\%20o\%20radu\%20knji\%C5\%BEnice.pdf
} 
zbirki te postojanje pisanih dokumenata fakulteta i knjižnice kojima je uređena nabava i izgradnja knjižničnih zbirki.

Rezultati istraživanja pokazuju da se pojam nabava knjižnične građe u više od polovine knjižnica pojavljuje samo u godišnjem proračunu matične ustanove, a većina ju definira u pravilnicima o radu knjižnice, što su potvrdili i intervjui s voditeljima visokoškolskih knjižnica. Međutim kod onih visokoškolskih knjižnica koje nabavu knjižnične građe navode u pravilnicima o radu knjižnice navedena je samo kao jedna od knjižničnih djelatnosti.

Samo jedna knjižnica detaljno navodi koje će se zbirke popunjavati i kroz koje načine nabave te za koje korisničke skupine, što upućuje na nedostatnu zainteresiranost i samih knjižničara.

Nadalje pregledavajući pravilnike o radu knjižnica koje su obuhvaćene ispitivanjem, vidljivo je da kod većine knjižnica voditelji kao članovi knjižničnih odbora sudjeluju u nabavi knjižnične građe, ali i na to da u nekim knjižnicama voditelj nema nikakvu ulogu u nabavnoj politici, što je zabrinjavajuće. Također u jednoj od knjižnica knjižnični odbor više ne postoji, što prema novom Zakonu o knjižnicama više nije obveza.

Smjernice ima manji broj knjižnica. Iz intervjua je vidljivo da polovina ispitanika ne smatra da bi smjernice svake sastavnice trebale biti usklađene sa Smjernicama Gradske i sveučilišne knjižnice Osijek, dok drugi dio smatra da je to u praksi teško izvedivo s obzirom na to da svaka sastavnica ima svoju nabavnu politiku. Naime iako voditelji knjižnica svake godine dostavljaju Matičnoj službi za visokoškolske i specijalne knjižnice popis obvezne i izborne literature prema studijskim programima i izvedbenim planovima nastave pojedinih studija te se dio nabavljene knjižnične građe u Gradskoj i sveučilišnoj knjižnici Osijek odvaja za Studijsku čitaonicu, ipak je to nedovoljno s obzirom na to da je često riječ samo o jednom primjerku nabavljenog naslova.

Što se tiče edukacije koja bi im pomogla pri izradi vlastitih smjernica za nabavu knjižnične građe i tako olakšala nabavu, a s druge strane obvezala njihove uprave na sustavnu nabavnu politiku, dio ispitanika nije pokazao zainteresiranost. Razlog je tomu možda njihova trenutna uloga u nabavnoj politici, odnosno nesamostalnost pri izgradnji knjižničnih zbirki.

Rezultati pokazuju i da se godišnji proračun za nabavu knjižnične građa smanjuje. Zanimljivo je da u 2019. godini više od polovine ispitanika navodi i razmjenu kao izvor financijskih sredstava.

Odluke o nabavi knjižnične građe u najvećem broju knjižnica donosi isključivo dekan fakulteta na temelju prijedloga voditelja knjižnice i nastavnog osoblja, ali i voditelj knjižnice u dogovoru s nastavnim osobljem. Unatoč činjenici da vrlo mali broj knjižnica ima povlasticu da samostalno odlučuje o nabavi, raste broj knjižnica u kojima korisnici izravno predlažu nabavu na temelju baze desiderata. Nadalje 
više od polovine ispitanika prati izvedbene planove nastave i usklađuje knjižnične zbirke prema literaturi navedenoj u njima, što je više nego u 2015. godini. Uloga knjižničnih odbora u nabavi prisutna je samo u malom broju knjižnica.

U 2019. godini vidljiv je porast nabave određene vrste građe vezane uz pojedine kolegije. Većina ispitanika najčešće nabavlja obveznu literaturu, a gotovo polovina ispitanika navodi da često nabavlja seminarsku literaturu. Međutim primijećen je blagi pad u nabavi literature za znanstvenoistraživački rad, kao i u nabavi referentne građe. U 2015. godini nešto više od polovine ispitanika navodi nabavu te vrste građe, dok u 2019. godini samo petina. Također manje se kupuju i inozemna tiskana izdanja izravno od izdavača.

Iako raste pretplata na elektroničke knjige, smanjuje se nabava online baza podataka iz vlastitih sredstava. S druge strane u 2019. godini institucijske repozitorije imaju sve knjižnice.

Upitani o načinu vrednovanja nabavljene knjižnične građe, u 2015. godini najveći broj ispitanika navodi povratne informacije korisnika, dok se u 2019. godini povećava broj onih ispitanika koji provjeravaju pokrivenost predmetnih područja prema izvedbenim planovima studijskih programa. Gotovo polovina ispitanika navodi kvantitativne statističke podatke o učestalosti uporabe, a petina ispitanika citatnu analizu studentskih ocjenskih radova. U 2015. godini nijedan ispitanik ne navodi nijedan od tih dvaju načina vrednovanja knjižnične građe.

Iako je riječ o malom uzorku ispitanika, rezultati kvantitativnog dijela istraživanja pokazali su da nema velikih odstupanja u oba promatrana razdoblja, postoje blaga odstupanja u pozitivnom ili negativnom smjeru, ali neznatno. Međutim opći je zaključak na temelju rezultata provedenih istraživanja da uprave sastavnica Sveučilišta J. J. Strossmayera ne smatraju da su knjižnice sa svojim zbirkama građe i uslugama važne za kvalitetu nastavnog i znanstvenog rada, što se može promijeniti na temelju zahtjeva akreditacijskih izvješća u kojima se ta uloga knjižnica sve više ističe. S druge strane rezultati istraživanja upućuju i na nedostatan angažman samih knjižničara koji bi u suradnji s matičnom razvojnom službom trebali biti proaktivniji.

\section{Zaključak}

Razvoj knjižničnih zbirki jedan je od najvažnijih procesa unutar knjižničnog poslovanja i pretpostavka je za ostale aktivnosti u upravljanju knjižnicom. U radu su navedene definicije uvaženih teoretičara kojima je zajedničko da izgradnju zbirke promatraju u kontekstu prikupljanja, okupljanja i organizacije, odnosno odabira i načina nabave knjižnične građe, a upravljanje knjižničnim zbirkama definiraju kao širi pojam koji obuhvaća niz procesa koji su uključeni u upravljanje pristupom, vrednovanje i zaštitu informacijskih izvora. 
Neprestani tehnološki razvoj, novi načini znanstvenog komuniciranja i promjene u obrazovanju stavljaju pred visokoškolske knjižnice izazove u prilagodbi mijenjanja tradicionalnog koncepta knjižničnih zbirki. Umjesto promatranja zbirki kroz vlasništvo knjižnice smještene u jednom fizičkom prostoru, zbirke treba promatrati kao informacijske izvore kojima knjižnica upravlja, pruža ih i diseminira korisnicima bez obzira na mjesto informacijskih izvora. Da bi ispunile svoju obrazovnu, informacijsku i komunikacijsku zadaću i odgovorile na promjene, visokoškolske knjižnice moraju imati jasne i zacrtane ciljeve određene strategijskim planom razvoja. Izgradnji zbirki moraju prethoditi pomno razrađeni postupci.

U sve većem porastu dokumenata i e-izdavaštva nijedna knjižnica, pa tako ni visokoškolska, ne može sama zadovoljiti sve potrebe korisnika bez suradnje i usklađene izgradnje knjižničnih zbirki u sveučilišnom knjižničnom sustavu kroz koordiniranu nabavu. Problem u radu knjižničnih sveučilišnih sustava u Hrvatskoj $^{74}$, pa tako i osječkog, proizlaze iz nepostojanja jedinstvene strategije razvoja i zakonskih rješenja koja podupiru promjene u okruženju te zastarjelosti standarda za visokoškolske knjižnice, a očituju se u nevidljivosti knjižnične djelatnosti i knjižničnih djelatnika ${ }^{75} \mathrm{u}$ sustavu visokog obrazovanja, u nepovezanosti knjižnica u sustavu, pogotovo kad je riječ o nabavi informacijskih izvora i pružanju informacijskih usluga, što je na kraju posljedica i neracionalnog trošenja proračunskih sredstava. ${ }^{76}$

Pozitivni je pomak koordinirana konzorcijska nabava elektroničkih časopisa preko već spomenutog projekta e-Izvori. No moramo si postaviti pitanja: Što će biti kada završi projekt? I ne bude obnovljen? Hoće li korisnici razumjeti da knjižnični djelatnici koji su uvijek odmah odgovarali na njihove zahtjeve sada na njih ne mogu odgovoriti jer ti izvori više nisu dostupni? Hoće li razumjeti da će o tome opet odlučiti „netko“, a ne knjižnica?

Usprkos ograničenjima provedenog istraživanja (veličina uzorka, nejednak broj ispitanika), rezultati predstavljeni u ovome radu pokazuju da knjižnice Sveučilišta u Osijeku imaju nekoliko zajedničkih elemenata u procesu nabave: smanjeni godišnji proračun za nabavu knjižnične građe, smanjenu pretplatu na online baze podataka iz vlastitih sredstava, a nabavu knjižnične građe definiraju samo u pravilnicima o radu knjižnice; s druge pak strane kontinuiranu nabavu i pokrivenost tiskane knjižnične građe prema izvedbenim planovima studijskih programa i povećanu nabavu elektroničkih knjiga te nove načine vrednovanja nabavljene knjižnične građe. Naime povećava se broj onih ispitanika koji provjeravaju pokrivenost predmetnih područja prema izvedbenim planovima studijskih programa,

${ }_{74}$ Usp. Majstorović, Z.; K. Ivić. Nav. dj., str. 45

75 Nažalost, knjižnične djelatnike u matičnim ustanovama još uvijek percipiraju kao administrativno osoblje, a ne kao stručne suradnike u nastavi. Isto tako i matično Sveučilište u službenim podacima knjižnične djelatnike svrstavaju u kategoriju administrativnog osoblja.

76 Usp. Majstorović, Z.; K. Ivić. Nav. dj., str. 45 
rabe kvantitativne statističke podatke o učestalosti uporabe i provode citatnu analizu studentskih ocjenskih radova.

Možemo zaključiti da sve knjižnice u sastavu Sveučilišta u Osijeku nemaju osiguran proračun, što ima za posljedicu stihijsku nabavu knjižnične građe i oslanjanje na vlastite snage.

Prijedlog za poboljšanje kvalitete knjižničnih zbirki autorice ovog rada vide u sustavnoj nabavnoj politici kroz standardizirane i dobro razrađene postupke istraživanja potreba korisnika, definirane vrste, opseg i sadržaj pojedinih zbirki, utvrđene kriterije odabira knjižnične građe, planiranje oblika i načina nabave, definiranje kriterija za nabavu tradicionalnih i digitalnih zbirki i online izvora dajući prednost jednoj, odnosno drugoj vrsti, utvrđene procedure i hijerarhije donošenja odluka o nabavi i raspodjeli sredstava i kontinuirano vrednovanje i pročišćavanje knjižnične građe.

Sustavna nabavna politika i kvalitetnija izgradnja knjižničnih zbirki postigla bi se definiranjem gore navedenih pisanih dokumenata i procedura unutar knjižnica sastavnica Sveučilišta u Osijeku te prihvaćanjem i obvezom matičnih ustanova knjižnica sastavnica u njihovoj provedbi. Postojanje takvih transparentnih okvira doprinijelo bi zajedničkoj, usklađenoj izgradnji zbirki u sveučilišnom knjižničnom sustavu na lokalnoj, a u budućnosti i na nacionalnoj razini.

\section{LITERATURA}

Aparac-Jelušić, T. Utjecaj promjena u akademskom obrazovanju na preoblikovanje knjižničnih službi i usluga. // Glasnik društva bibliotekara Split 7(2000), 39-51.

Aparac-Jelušić, T.; M. Dragija. Pristup i metodologija istraživanja kvalitete zbirki u knjižnicama visokih učilišta. // Glasnik društva bibliotekara Split 7(2000), 162-168.

Bullis, D. R.; L. Smith. Looking back, moving forward in the digital age: a review of the collection management and development literature, 2004-8. // University Libraries Faculty Scholarship 26(2011), 205-220.[citirano: 2020-07-30]. Dostupno na: https:// scholarsarchive.library.albany.edu/ulib_fac_scholar/26/.

Clayton, P.; G. E. Gorman. Managing information resources in libraries: collection management in theory and practice. London: Library Association Publishing, 2001.

Corrall, S.; R. Angharad. Information resource development and "collection" in the digital age: conceptual frameworks and new definitions for the network world. // Changes in the world of electronic resources: Information and digitization, 20 June 2012 - 22 June 2012, Zadar, Croatia. [ citirano: 2020-07-30]. Dostupno: http://d-scholarship.pitt.edu/25171/. 
Evans, G. E.; M. Saponaro Zarnowski. Developing library and information center collections. 5th ed. Wesport; London: Libraries Unlimited, 2005.

Financijski planovi i odluke o prihvaćanju za 2020. [citirano: 2020-10-16]. Dostupno na: https://www.gskos.unios.hr/wp-content/uploads/2019/12/odluka-4-javna-nabava.pdf.

Golubović, V. Nabava knjižnične građe u funkciji izgradnje knjižnične zbirke // HKD Novosti 76(2018). [citirano: 2020-08-20]. Dostupno na: https://www.hkdrustvo.hr/ hkdnovosti/clanak/1449.

Gorman, M.. Collection development in interesting times: a summary. // Library Collections, Acquisitions and Technical Services 27, 4(2003), 459-462. DOI: https://doi. org/10.1080/14649055.2003.10765950.

Grujić, T. Nabava literature za potrebe Sveučilišta u Puli: možemo i bolje! // 13. dani specijalnih i visokoškolskih knjižnica: zbornik radova, Opatija 2013. / ur. Ivana Hebrang Grgić i Vesna Špac. Zagreb: Hrvatsko knjižničarsko društvo, 2014. Str. 309318.

Hergešić, B. O nabavi i nabavnoj politici. // Vjesnik bibliotekara Hrvatske 5, 1-4(19581959), 9-23.

Horava, T. Challenges and possibilities for collection management in a digital age. // Library Resources \& Techical Services 54, 3(2010), 144-145. DOI: https://doi. org/10.5860/lrts.54n3.142.

Izvješće o radu Gradske i sveučilišne knjižnice Osijek za 2019. [citirano: 2020-1016]. Dostupno na: https://www.gskos.unios.hr/wp-content/uploads/2020/05/gisko2019-1205-compressed.pdf.

Knjižnica kliničkog bolničkog centra u Osijeku [citirano: 2020-08-11]. Dostupno na: http://www.kbco.hr/znanost/knjiznica/.

Knjižnica Veleučilišta Lavoslav Ružička u Vukovaru [citirano:2020-08-11]. Dostupno na: https://www.vevu.hr/?i=138.

Knjižnica Veleučilišta u Požegi [citirano: 2020-08-11]. Dostupno na: https://www.vup. hr/o_nama/sluzbe/knjiznica/default.aspx.

Knjižnica Veleučilišta u Slavonskom Brodu, [citirano: 2020-08-11]. Dostupno na: https://www.unisb.hr/.

Krajna, T.; H. Markulin. Nabava knjižnične građe u visokoškolskim knjižnicama. // Vjesnik bibliotekara Hrvatske 54, 3(2011), 21-42. Dostupno i na: https://www.hkdrustvo.hr/vjesnik-bibliotekara-hrvatske/index.php/vbh/article/view/358. [citirano: 2020-07-30].

Kriteriji i metode vrednovanja AV građe i multimedije u narodnim knjižnicama: pregled. [citirano: 2020-10-16]. Dostupno na: https://www.gskos.unios.hr/wp-content/ uploads/2017/03/Kriteriji-i-metode-vrednovanja-AV-grade-i-multimedije.pdf. 
Leonhardt, T. The gifts and exchange function in ARL libraries: now and tomorrow. // Library Acquisitions: Practice \& Theory 21, 2(1997), 141-149.

Leščić, J.; Z. Majstorović. Conspectus model IFLA-e: prikaz načela i njihove primjene u praksi. // 11. dani specijalnih i visokoškolskih knjižnica, Opatija, 2009.: zbornik / ur. Tamara Krajna i Alisa Martek. Zagreb: Hrvatsko knjižničarsko društvo, 2010. Str. 288-297.

Lewis, J. S. An assessment of publisher quality by political science librarians. // College \& Research Libraries 61, 4(2000), 313-323.

Majstorović, Z.; K. Ivić. Izgradnja zbirki u sveučilišnom knjižničnom sustavu: model. // Vjesnik bibliotekara Hrvatske 54, 3(2011), 43-67. Dostupno i na: https://www. hkdrustvo.hr/vjesnik-bibliotekara-hrvatske/index.php/vbh/article/view/359. [citirano: 2020-07-30].

Martek, A. Konzorcijska nabava u Hrvatskoj: stanje i perspektiva. // Vjesnik bibliotekara Hrvatske 54, 3(2011), 79-94. Dostupno i na:https://www.hkdrustvo.hr/vjesnik-bibliotekara-hrvatske/index.php/vbh/article/view/361. [citirano: 2020-07-30].

Mihel, I.; V. Gržetić. Nabava časopisa u 2002. godini: konzorcijski pristup: korak ka ažurnijem i obuhvatnijem informiranju. // Kemija u industriji 51, 6(2002), 285-289.

Peleš, G. Nabavna politika kao pokazatelj odnosa između sveučilišnih (fakultetskih) biblioteka i Nacionalne i sveučilišne biblioteke. // Vjesnik bibliotekara Hrvatske 33, 1-4(1990), 53-56.

Pravilnik o radu Knjižnice. [citirano: 2020-10-17]. Dostupno na: http://www.ptfos. unios.hr/images/dokumenti/na-razini-fakulteta/pravilnik-o-radu- knjiznice.pdf.

Pravilnik o radu Knjižnice Fakulteta za odgojne i obrazovne znanosti. [citirano: 202010-17]. Dostupno na: https://www.foozos.hr/dokumenti/knjiznica/Pravilnik\%20 o\%20radu\%20knji\%C5\%BEnice.pdf.

Pravilnik o radu Knjižnice Odjela za matematiku. [citirano: 2020-10-17]. Dostupno na: https://www.mathos.unios.hr/images/homepages/bgrasa/Pravilnik_o_radu_knjiznice_Odjela_za_matematiku.pdf.

Program rada knjižnične djelatnosti Gradske i sveučilišne knjižnice Osijek za 2020 godinu. [citirano: 2020-10-16]. Dostupno na: https://www.gskos.unios.hr/wp-content/ uploads/2019/12/Program-rada-2020..pdf.

Projekt e-Izvori. [citirano: 2020-08-30]. Dostupno na: http://baze.nsk.hr/projekt-e-izvori/.

Sastavnice Sveučilišta Josipa Jurja Strossmayera u Osijeku. [citirano: 2020-08-11]. Dostupno na: http://www.unios.hr/o-sveucilistu/sastavnice/.

Siber, Lj.; S. Lukačević. Otkup knjiga Ministarstva kulture i Ministarstva znanosti, obrazovanja i sporta: utjecaj na izgradnju knjižnog fonda Gradske i sveučilišne knjižnice Osijek u razdoblju od 1998. do 2013. // Vjesnik bibliotekara Hrvatske 60, 2-3(2017), 80-100. Dostupno i na: https://www.hkdrustvo.hr/vjesnik-bibliotekara-hrvatske/index.php/vbh/article/view/578. [citirano: 2020-07-30]. 
Smjernice za nabavu Gradske i sveučilišne knjižnice Osijek, Služba nabave. [citirano: 2020-10-16]. Dostupno na: https://www.gskos.unios.hr/wp-content/uploads/2017/03/Smjernice-za-nabavu-GISKO1.pdf.

Smjernice za postupak pri darivanju građe Gradske i sveučilišne knjižnice Osijek. [citirano: 2020-10-16]. Dostupno na: https://www.gskos.unios.hr/wp-content/uploads/2017/03/Smjernice-za-postupak-pri-darivanju-gradje-GISKO1.pdf.

Standardi za visokoškolske knjižnice u Republici Hrvatskoj. // Vjesnik bibliotekara Hrvatske 33, 1-4(1990), 201-210.

Statut Gradske i sveučilišne knjižnice Osijek. [citirano: 2020-10-16]. Dostupno na: https:/www.gskos.unios.hr/wp-content/uploads/2017/02/STATUT.pdf.

Stouthuysen, K.; M. Swiggers; A. Reheul; F. Roodhooft, Time-driven activity-based costing for a library acquisition process: a case study in a Belgian University. // Library Collections, Acquisitions, \& Technical Services 34, 2-3(2010), 83-91, DOI: 10.108 0/14649055.2010.10766264.

Šušak Lukačević, M.; S. Hasenay; I. Šuvak-Pirić. Izgradnja zbirke periodike razmjenom časopisa Mathematical comunications u knjižnici Odjela za matematiku Sveučilišta u Osijeku. // Knjižničarstvo 17, 2(2103), 57-74. [citirano: 2020-07-30]. Dostupno na: https://hrcak.srce.hr/239689.

Vrana, R.; J. Kovačević. Razvoj knjižničnih zbirki kao preduvjet i mjera razvoja knjižnice. // Vjesnik bibliotekara Hrvatske 60, 1(2017), 79-12. Dostupno i na: https:// www.hkdrustvo.hr/vjesnik-bibliotekara-hrvatske/index.php/vbh/article/view/538. [citirano: 2020-08-30].

Zakon o knjižnicama. // Narodne novine 105, 1616(1997). [citirano: 2019-08 18]. Dostupno na: https://narodne-novine.nn.hr/clanci/sluzbeni/1997_10_105_1616.html.

Zakon o knjižnicama i knjižničnoj djelatnosti. // Narodne novine 17, 356(2019). [citirano:2020-11-05]. Dostupno na: https://narodne-novine.nn.hr/clanci/sluzbeni/2019_02_17_356.html.

Zakon o znanstvenoj djelatnosti i visokom obrazovanju: pročišćeni tekst zakona: Narodne novine 123/2003, 198/2003, 105/2004, 174/2004, 2/2007, 46/2007, 45/2009, 45/2009, 63/2011, 94/2013, 139/2013, 101/2014, 60/2015, 131/2017 i 96/2018. // Zakon.hr. [citirano: 2019-08 18]. Dostupno na: https://www.zakon.hr/z/320/Zakon-o-znanstvenoj-djelatnosti-i-visokom-obrazovanju 